\title{
The Nutritional Quality Potential of Microgreens, Baby Leaves, and Adult Lettuce: An Underexploited Nutraceutical Source
}

\author{
Eva Martínez-Ispizua ${ }^{1}\left(\mathbb{D}\right.$, Ángeles Calatayud ${ }^{1}$, José Ignacio Marsal ${ }^{1}$, Claudio Cannata ${ }^{2}{ }^{(}$, Federico Basile ${ }^{2}(\mathbb{D}$, \\ Abdelsattar Abdelkhalik ${ }^{3}{ }^{D}$, Salvador Soler ${ }^{4}$, José Vicente Valcárcel ${ }^{4}$ and Mary-Rus Martínez-Cuenca ${ }^{1, * \mathbb{D}}$ \\ 1 Valencian Institute for Agricultural Research (IVIA), CV-315, Km 10.7, 46113 Valencia, Spain; \\ martinez_evaisp@externos.gva.es (E.M.-I.); calatayud_ang@gva.es (Á.C.); marsal_jos@gva.es (J.I.M.) \\ 2 Dipartimento di Agricoltura, Alimentazione e Ambiente (Di3A), University of Catania, Via Valdisavoia, \\ 95123 Catania, Italy; claudio.cannata@phd.unict.it (C.C.); federico.basile@phd.unict.it (F.B.) \\ 3 Horticulture Department, Faculty of Agriculture, Fayoum University, Fayoum 63514, Egypt; \\ aga04@fayoum.edu.eg \\ 4 Valencian Institute for the Conservation and Improvement of Agrobiodiversity (COMAV), \\ Polytechnic University of Valencia, Camino de Vera s/n, 46022 Valencia, Spain; salsoal@btc.upv.es (S.S.); \\ jvalcarc@btc.upv.es (J.V.V.) \\ * Correspondence: martinez_mru@gva.es
}

check for

updates

Citation: Martínez-Ispizua, E.;

Calatayud, Á.; Marsal, J.I.; Cannata,

C.; Basile, F.; Abdelkhalik, A.; Soler,

S.; Valcárcel, J.V.; Martínez-Cuenca,

M.-R. The Nutritional Quality

Potential of Microgreens, Baby

Leaves, and Adult Lettuce: An

Underexploited Nutraceutical Source.

Foods 2022, 11, 423. https://doi.org/

10.3390 /foods 11030423

Academic Editor: Carmine Summo

Received: 13 January 2022

Accepted: 29 January 2022

Published: 31 January 2022

Publisher's Note: MDPI stays neutral with regard to jurisdictional claims in published maps and institutional affiliations.

Copyright: (C) 2022 by the authors. Licensee MDPI, Basel, Switzerland. This article is an open access article distributed under the terms and conditions of the Creative Commons Attribution (CC BY) license (https:// creativecommons.org/licenses/by/ $4.0 /)$

\begin{abstract}
Interest in the cultivation of lettuce landraces is increasing because native varieties, as high-quality products, are particularly attractive to consumers. Lettuce is a popular leafy vegetable worldwide, and interest in the consumption of first leaves (microgreens) and seedlings (baby leaves) has grown due to the general belief that young plants offer higher nutritional value. The content of some bioactive compounds and antioxidants (chlorophylls, carotenoids, anthocyanins, ascorbic acid, phenols, antioxidant activity) was monitored in six lettuce landraces and five commercial varieties, and compared across three development stages: microgreen, baby, and adult. Ascorbic acid and phenolic contents were $42 \%$ and $79 \%$ higher, respectively, in the early stages than in adult lettuces, and red-leaf varieties (CL4 and L11) stood out. This finding agrees with lettuce's marked antioxidant capacity and correlates with its pigment contents, especially anthocyanins. The nutritional value of adult lettuce is conditioned by its size, shape, and head structure as phytochemical concentrations are regulated by light. The low content of ascorbic acid, phenolics, and anthocyanins in crisphead lettuce (CL5) is a clear example ( $49,67 \%$, and $27 \%$ lower, respectively, than the adult mean). Our results indicate the wide variability of lettuces' nutritional characteristics and emphasize that traditional varieties are a helpful source of agricultural biodiversity.
\end{abstract}

Keywords: antioxidant; biodiversity; baby leaf; landrace; lettuce; microgreen; mineral; nutraceutical compound

\section{Introduction}

Lettuce (Lactuca sativa L.) is a popular and widely grown leafy vegetable worldwide, especially as a component of salad mixes, whose consumption is increasing. Lettuce can contribute significantly to the nutritional content of diets [1]. In recent years, general consumer and researcher concern has been voiced about foods that, beyond nutritional needs, also provide health beneficial effects, for example, promote well-being, reduce diseases, and prolong life span. These effects are related to the nutritional quality of vegetables (minerals, vitamins, and phytochemicals with considerable antioxidant potential) [2,3].

The biosynthesis, composition, and concentration of health-promoting compounds varies widely among leafy vegetables, and are influenced by the genetic and environmental factors, growing conditions, harvest practices, and postharvest handling conditions [4]. As lettuce is generally eaten raw, more nutrients are preserved than in other cooked or processed vegetables, such as potatoes. Nevertheless, lettuce has not been regarded as a 
nutritional food, primarily because of its high water content (around 95\%); however, its nutrient composition may be equivalent to other vegetables [5]. In lettuce, different plant attributes, such as leaf color, may influence the nutritional quality. One clear example is leaf pigmentation, which is often associated with the presence of antioxidant compounds. Red lettuce is highlighted for its lipophilic antioxidant activity and ascorbic acid and phenolic contents compared to other leafy vegetables (chicory, green lettuce, lamb's lettuce, mizuna, red chard, red lettuce, rocket, spinach, Swiss chard, tatsoi), especially when exposed to low photosynthetically active radiation (PAR) light intensity. At high PAR, green lettuce has also been observed to have high contents of phenolic compounds [6]. In 11 lettuce cultivars, Lata and Przeradzka [7] determined that the antioxidant capacity provided by the glutamic acid and ascorbic acid contents was higher in the cultivars Kobra, Marion, and Red Bowl. Gazula et al. [8] worked with nine lettuce cultivars with differing numbers of genes to regulate carotene synthesis in them, and found that the highest pigment concentrations were found in the cultivars with the most genes in question. Comparisons of lettuces' mineral contents are limited by the wide variation in the mineral contents reported in studies. This may be due to factors, such as different soil mineral compositions [9] and lettuce head types [10]. Studies have generally reported that lettuce is a relatively good source of Fe and little Na. Overall, among plant types, the mineral content was higher in butterhead, romaine, and leaf lettuces than in crisphead (iceberg) [11]. As lettuce is characterized by a marked ability to accumulate nitrate in the leaves, a low concentration is considered one of the most important healthy parameters, which is influenced by both genetic and environmental factors, especially light intensity [12].

Finally, plant age is interesting given the general belief that young plants have a higher nutritional value [13]. Consumption of first-development leaves (microgreens) to add texture and flavor to various dishes and salads consisting of seedlings (baby leaves) has gained popularity as a culinary trend [14,15]. This trend has been driven by two important market chain memberships: (1) growers, whose marketing strategy seeks to diversify the product offered and reduce cultivation periods to obtain higher profits; and (2) consumers, who are constantly searching for potential nutritional food and can make the most of microgreens' easy at-home cultivation, especially as its availability in shops is scarce. So, given the popularity of lettuce worldwide, microgreens and baby types constitute a novel functional food that combines high sensory and bioactive values. This inspires comparisons with their mature-leaf counterparts, particularly as very few studies have examined their vitamin, nutrient, and carotenoid contents $[9,15]$ and even fewer have provided comparative evidence of the phytochemical content of microgreens and baby leaves as opposed to their mature-leaf counterparts. The studies of Pinto et al. [9] and Weber [16] solely addressed the comparative mineral profiles of mature leaves and microgreens. El-Nakhe et al. [17] compared some nutraceutical compounds (chlorophylls, vitamin C, carotenes, phenolics), but this study was carried out with only two lettuce varieties at two harvest times (microgreen and adult).

Another factor that induces variations in the nutritional quality of lettuce is the genetic material. Although there is compelling evidence for a declining nutritional value of horticultural crops, which is attributed to both changes in agricultural practices and the replacement of landraces with modern varieties and hybrids, promising new diet sources lie in local landraces, underutilized crops, and edible wild plants [18].

Hence, this study aimed to report the nutritional value of lettuce in relation to its different morphologies (color and head structure) and three harvest stages (microgreens, baby leaves, and adults) to determine the best health beneficial candidates that provide the highest nutritional value and bioactive compounds. Finally, it compared six Valencian lettuce landraces and five similar commercial varieties, and values, such as the usefulness of local varieties as a source of biodiversity. 


\section{Materials and Methods}

\subsection{Plant Material}

The plant material for this study consisted of 11 lettuce (Lactuca sativa L.) varieties, including 6 landraces from the Valencian Community (Spain), which are diverse regarding their leaf color and head morphology. Seeds were provided by the Valencian Institute for the Conservation and Improvement of Agrobiodiversity (COMAV-UPV, Valencia, Spain) and the Valencian Institute of Agrarian Research (IVIA, Moncada, Spain). In addition, five commercial varieties were chosen as the most representative of the market formats. Table 1 provides the technical information of each variety. Figure $1 \mathrm{~A}, \mathrm{~B}$ complement this table.

A
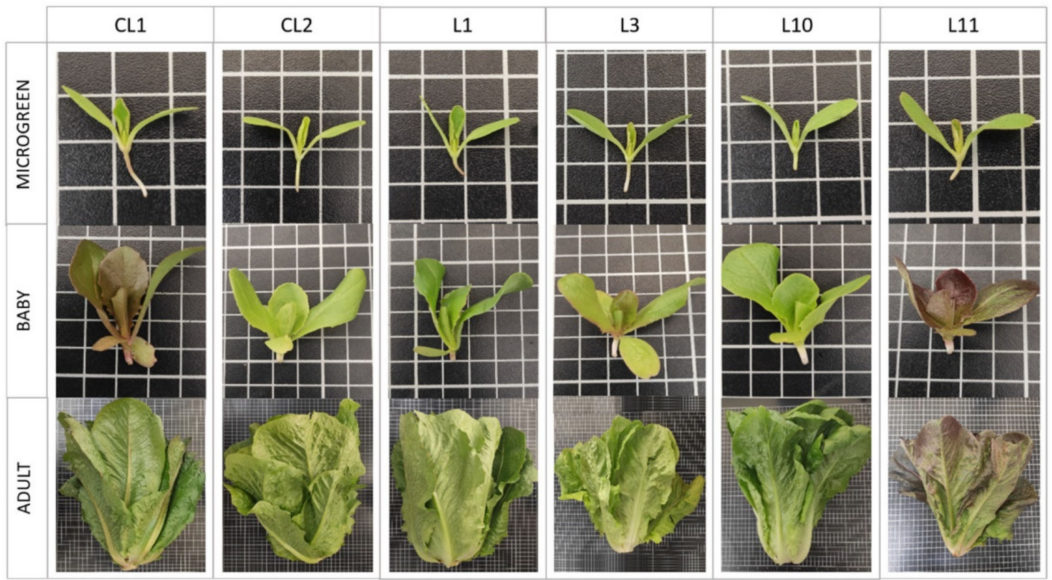

B

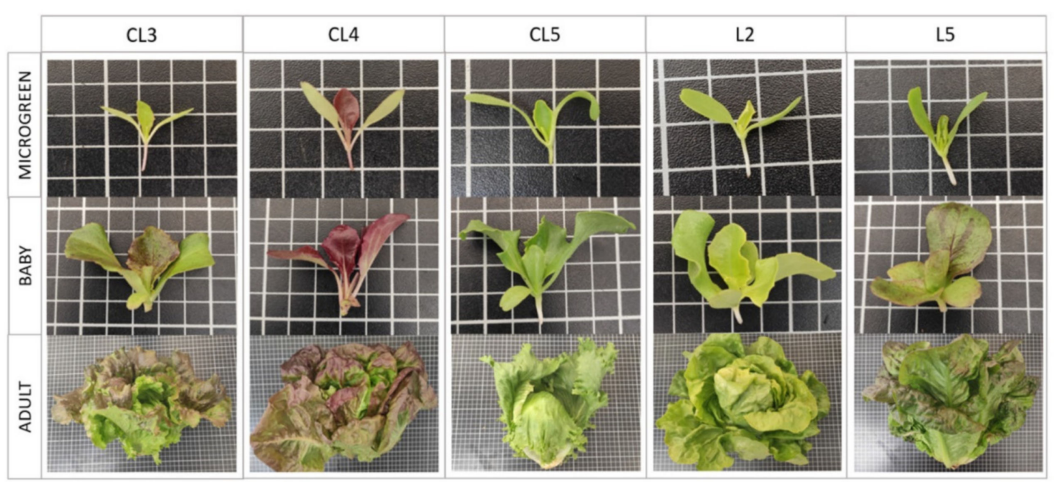

Figure 1. Pictures of the 11 cultivated lettuce varieties (Lactuca sativa L.) in the 3 development stages (microgreen, baby, adult) provided by the Germplasm Banks from the COMAV and the IVIA (Spain). The size of the grid cells in the fruit pictures is $0.01 \mathrm{~m} \times 0.01 \mathrm{~m}$. (A): Lettuce varieties without a patent head; (B): lettuce varieties with a prominent head.

Table 1. Abbreviation, origin, identification, and short phenotypic description of the 11 lettuce varieties used in this study. The plant material from local landraces was provided by the: (1) Valencian Institute for the Conservation and Improvement of Agrobiodiversity (COMAV, Valencia, Spain); (2) Valencian Institute for Agricultural Research (IVIA, Moncada, Spain).

\begin{tabular}{|c|c|c|c|}
\hline $\begin{array}{l}\text { Abbreviation } \\
\text { Code }\end{array}$ & Origin & Identification & Plant Description \\
\hline CL1 & Commercial & $\begin{array}{l}\text { Romaine lettuce long mule } \\
\text { ear (Battle) }^{\text {a }}\end{array}$ & $\begin{array}{c}\text { Dark green. Elongated shape. Compact and narrow head, } \\
\text { barely prominent. }\end{array}$ \\
\hline CL2 & Commercial & $\begin{array}{l}\text { Romaine lettuce from the } \\
\text { gardeners (Vilmorín) }^{a}\end{array}$ & $\begin{array}{c}\text { Green-yellowish. Elongated shape. Compact and narrow head, } \\
\text { barely prominent. }\end{array}$ \\
\hline CL3 & Commercial & Wonder summer (Battle) ${ }^{a}$ & $\begin{array}{l}\text { Green with reddish shades. Remarkable width in relation to } \\
\text { height. Compact, rounded and quite prominent head. }\end{array}$ \\
\hline
\end{tabular}


Table 1. Cont.

\begin{tabular}{|c|c|c|c|}
\hline $\begin{array}{l}\text { Abbreviation } \\
\text { Code }\end{array}$ & Origin & Identification & Plant Description \\
\hline CL4 & Commercial & $\begin{array}{l}\text { Marvel of Four Seasons } \\
\text { Butterhead (Battle) }{ }^{a}\end{array}$ & $\begin{array}{l}\text { Dark green with reddish shades; the red is prominent at the } \\
\text { edges. Round shape. Quite rounded shape. Full-sized head. }\end{array}$ \\
\hline CL5 & Commercial & $\begin{array}{l}\text { Batavia, iceberg type } \\
\text { (Battle) }^{\text {a }}\end{array}$ & Not very intense green. Rounded shape. Full-sized head. \\
\hline L1 & Local landrace & BGV $5721^{b, 1}$ & $\begin{array}{l}\text { Dark green. Pink shades near the principal stem. Elongated } \\
\text { shape. Compact and narrow head, barely prominent. }\end{array}$ \\
\hline L2 & Local landrace & BGV5722 b,1 & Green-yellowish. Round shape. Full-sized head. \\
\hline L3 & Local landrace & BGV5723 b,1 & $\begin{array}{l}\text { Green-yellowish. Remarkable width in relation to height. Head } \\
\text { not appreciated. }\end{array}$ \\
\hline L5 & Local landrace & BGV5736 b,1 & $\begin{array}{l}\text { Dark green with reddish shades. Elongated shape. Compact } \\
\text { and narrow head, quite prominent. }\end{array}$ \\
\hline L10 & Local landrace & $\mathrm{L}-10^{\mathrm{b}, 2}$ & $\begin{array}{c}\text { Dark green. Elongated shape. Compact and narrow head, } \\
\text { barely prominent. }\end{array}$ \\
\hline L11 & Local landrace & $\mathrm{L}-11^{b, 2}$ & $\begin{array}{l}\text { Dark red, almost purple. Remarkable width in relation to } \\
\text { height. Head not appreciated. }\end{array}$ \\
\hline
\end{tabular}

${ }^{a}$ Commercial name (company), ${ }^{b}$ Genbank code.

\subsection{Greenhouse-Field Experiments}

Experiments were conducted from November to March in the IVIA experimental installations in Moncada (Valencia, Spain; 39 $35^{\prime} 22.3^{\prime \prime} \mathrm{N}, 0^{\circ} 23^{\prime} 44.0^{\prime \prime} \mathrm{W}, 37 \mathrm{~cm}$ above sea level). Seeds were sown in November 2020 in 104-hole trays with 100\% natural coconut coir fiber substrate (225 g L ${ }^{-1}$ density, Cocopeat, Projar Co., 46930 Quart de Poblet, Valencia, Spain) under greenhouse conditions (natural light conditions with a maximum PAR of $1000 \mu \mathrm{mol} \mathrm{m}{ }^{-2} \mathrm{~s}^{-1}$, a mean temperature of $21^{\circ} \mathrm{C}$, and a mean humidity of $60 \%$ ).

Two weeks after germination, the first group of seedlings (microgreen stage) was collected, after ensuring that the first true leaf had appeared, by cutting seedlings at the substrate level. Each microgreen sample comprised at least 20 seedlings, and each landrace or commercial variety consisted of 5 replicates.

A second group of plants was moved to an unheated greenhouse, where the temperature and light incidence were the same as in the external environment, thus preventing seedling thinning caused by high temperatures. Seedlings were protected from wind and potential pests while growing until the majority of the plants were $5 \mathrm{~cm}$ high (around 4 weeks after germination) after ensuring that at least 4 true leaves had appeared. One subgroup of seedlings was collected (baby stage) by cutting seedlings at the substrate level. Each landrace or commercial variety consisted of 4 replicates, with at least 10 seedlings each. The average range of the minimum and maximum temperatures was $4-26{ }^{\circ} \mathrm{C}$ for November and $-1-26^{\circ} \mathrm{C}$ for December.

Finally, a second subgroup of seedlings was transplanted on 4 December 2020, and grown under field conditions. Each landrace or commercial variety consisted of 20 plants grown in 2 separate replicates (10 single plants each) cultivated in single rows $(110 \mathrm{~cm}$ apart) with 30 - and $60-\mathrm{cm}$ spacings between each plant and variety, respectively. The plot was surrounded by border rows on all four sides. The soil composition within a depth of $20 \mathrm{~cm}$ was $68 \%$ sand, $11 \%$ clay, and $21 \%$ silt (sandy-clay loam), and contained $0.61 \%$ organic matter, $0.051 \%$ total $\mathrm{N}$, less than $8 \mathrm{mg} \mathrm{kg}^{-1} \mathrm{P}, 301 \mathrm{mg} \mathrm{kg}^{-1} \mathrm{~K}$, and $2.87 \mathrm{meq} \cdot 100 \mathrm{~g}^{-1}$ assimilable $\mathrm{Mg}$. The soil electrical conductivity was $0.290 \mathrm{dS} \mathrm{m}^{-1}$ and $\mathrm{pH}$ was 8.1.

Irrigation satisfied 100\% crop evapotranspiration (ETc), as described in Penella et al. [19], performed with a drip system. Nutrients were applied by an irrigation system at a rate $\left(\mathrm{kg} \mathrm{ha}^{-1}\right.$ ) of $200 \mathrm{~N}, 50 \mathrm{P}_{2} \mathrm{O}_{5}, 250 \mathrm{~K}_{2} \mathrm{O}, 110 \mathrm{CaO}$, and $35 \mathrm{MgO}$, as recommended by Maroto [20]. The average range of the minimum and maximum temperatures during the field experiment was $1-23^{\circ} \mathrm{C}$ for December, $-1-26^{\circ} \mathrm{C}$ for January, $7-24{ }^{\circ} \mathrm{C}$ for February, and $6-26^{\circ} \mathrm{C}$ for March. Plants (adult stage) were harvested on 16 March. 


\subsection{Leaf Sample Preparation}

For the microgreens and baby material, 8 different replicates $(2 \mathrm{~g}$ of vegetal material per replicate) of each variety were obtained by randomly grouping seedlings (around 20 and 10 plants per replicate for microgreens and baby, respectively). Four of these replicates were reserved for stove drying. The remaining fresh samples were instantly frozen in liquid nitrogen and stored at $-80^{\circ} \mathrm{C}$. Of the adult plants, 4 different replicates ( 1 individual lettuce each replicate) were harvested from the field. Lettuce was cut lengthwise into four halves. A fraction of each lettuce was set aside for drying. A second fraction was chopped and instantly frozen in liquid nitrogen and stored at $-80^{\circ} \mathrm{C}$.

The plant material reserved for drying was used for the mineral analysis and dry weight (DW) quantification while the samples stored at $-80{ }^{\circ} \mathrm{C}$ were employed for nutraceutical quality determinations. Samples were ground in a mixer mill (MM400, Retsch, Hann, Germany) with liquid nitrogen to prevent melting. The same machine was used to homogenize the samples dried in a laboratory oven at $65^{\circ} \mathrm{C}$ for $72 \mathrm{~h}$.

\subsection{Nutraceutical Compounds and Antioxidant Capacity}

\subsubsection{Chlorophyll and Carotenoid Concentration}

Total chlorophyll (Chl) $\mathrm{a}+\mathrm{b}$ and carotenoids (Car) concentration were determined spectrophotometrically as described by Porra et al. [21]. Briefly, $2.5 \mathrm{~mL}$ of $80 \%$ acetone $(v / v)$ were added to the sample extracts $(0.06 \mathrm{~g} \mathrm{FW})$ and centrifuged at $2000 \mathrm{rpm}$ for $8 \mathrm{~min}$. The supernatant was used for the analysis. Solution absorption was measured at 663.6, 646.6, and $470 \mathrm{~nm}$ using a spectrophotometer (Lambda 25 UV/VIS, Perkin Elmer, Waltham, MA, USA). Then, $80 \%$ acetone $(v / v)$ was utilized as the blank solution. The chlorophyll and carotenoid contents of the extracts were calculated by the following equations:

(1) $\mathrm{Chl} \mathrm{a}=12.25 \times$ Abs663.6 - $2.79 \times \operatorname{Abs646.6}\left(\mu \mathrm{g} \mathrm{mL}^{-1}\right)$

(2) $\mathrm{Chl} \mathrm{b}=21.3 \times \operatorname{Abs646.6}-5.1 \times \operatorname{Abs663.6}\left(\mu \mathrm{g} \mathrm{mL}^{-1}\right)$

(3) $\mathrm{Car}=[(1000 \times \mathrm{Abs} 470-1.82 \mathrm{Chl} \mathrm{a})-(85.02 \times \mathrm{Chl} \mathrm{b})] / 198\left(\mu \mathrm{g} \mathrm{mL}^{-1}\right)$

(4) $\mathrm{Chl} \mathrm{a}+\mathrm{b}=7.15 \times$ Abs663.6 $+18.71 \times 646.6$

Chlorophylls and carotenoids were expressed as $\mu \mathrm{g} \mathrm{g}^{-1} \mathrm{FW}$.

\subsubsection{Anthocyanin Concentration}

The anthocyanin (Ant) concentration was spectrophotometrically quantified as described by Szepesi et al. [22]. In total, $5 \mathrm{~mL}$ of methanol: $\mathrm{HCl}: \mathrm{H}_{2} \mathrm{O}$ solution (90:1:9) were added to $0.1 \mathrm{~g}$ of FW of the homogenized sample previously placed in glass tubes. Samples were vortexed and stored in the dark for $1 \mathrm{~h}$. The samples in the tubes were mixed at room temperature. Then, they were centrifuged at $2000 \mathrm{rpm}$ for $5 \mathrm{~min}$ and the supernatant was used for the analysis. Solution absorption was measured at 534, 643, and $661 \mathrm{~nm}$ using a spectrophotometer (Lambda 25 UV /VIS, Perkin Elmer, Waltham, USA). Methanol: $\mathrm{HCl}_{2} \mathrm{H}_{2} \mathrm{O}$ solution was employed as the blank. The Ant content of the extracts was calculated by the following equation:

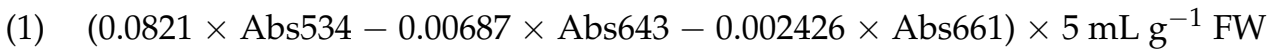

The anthocyanin concentration was expressed as $\mu \mathrm{mol} 100 \mathrm{~g}^{-1} \mathrm{FW}$.

\subsubsection{Ascorbic Acid Concentration}

The total ascorbic acid (AsA) content was spectrophotometrically quantified as described by Kampfenkel et al. [23]. First, $0.2 \mathrm{~g}$ FW of each homogenized sample were added to $1.5 \mathrm{~mL}$ of $6 \%(w / v)$ trichloroacetic acid (TCA). Samples were centrifuged at 15,000 rpm for $5 \mathrm{~min}$ at $4{ }^{\circ} \mathrm{C}$ and the supernatant was recovered. Then, $0.05 \mathrm{~mL}$ of the homogenate were mixed with $0.05 \mathrm{~mL}$ of $10 \mathrm{mM}$ dithiothreitol (DTT) and $0.1 \mathrm{~mL}$ of $0.2 \mathrm{M}$ phosphate buffer (pH 7.4). Samples were incubated for $15 \mathrm{~min}$ at $42{ }^{\circ} \mathrm{C}$. Next, $0.05 \mathrm{~mL}$ of $0.5 \%(w / v)$ $\mathrm{N}$-ethylamide (NEM) were added and incubated for $1 \mathrm{~min}$ at room temperature. Afterwards, $0.25 \mathrm{~mL}$ of $10 \%(w / v)$ TCA, $0.2 \mathrm{~mL}$ of H3PO $4 \%$ ( $(w / v), 0.2 \mathrm{~mL}$ of 2-2'-dipyridyl, and $0.1 \mathrm{~mL}$ of $3 \%(w / v) \mathrm{FeCl} 3$ were added to the solution. They were incubated together in 
a water bath for $40 \mathrm{~min}$ at $42^{\circ} \mathrm{C}$. The solution absorption was measured at $525 \mathrm{~nm}$ using a spectrophotometer (Lambda 25 UV/VIS, Perkin Elmer, Waltham, MA, USA). The blank

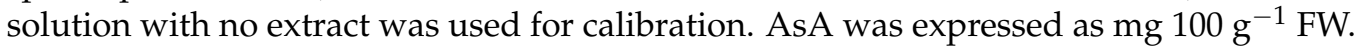

\subsubsection{Total Phenolic Analysis}

The phenolic (Phe) content was analyzed according to Dewanto et al. [24] with minor changes. Firstly, a $0.1 \mathrm{~g}$ FW aliquot of the homogenized sample was homogenized in $0.7 \mathrm{~mL}$ of $80 \%(\mathrm{v} / \mathrm{v})$ methanol, vortexed, incubated in an ultrasonic bath (Ultrasonic cleaner, Fungilab, Barcelona, Spain) at medium intensity for $30 \mathrm{~min}$, and then revortexed. Samples were centrifuged at $10,000 \mathrm{rpm}$ for $15 \mathrm{~min}$ at $4{ }^{\circ} \mathrm{C}$ and the supernatant was reserved. The total Phe content was determined by the Folin-Ciocalteau colorimetric method. Following this, a $20 \mu \mathrm{L}$ aliquot of the supernatant was mixed with $80 \mu \mathrm{L}$ of methanol and $0.7 \mathrm{~mL}$ of Folin-Ciocalteau reagent. This solution was vortexed and incubated in the dark for $5 \mathrm{~min}$ at room temperature. Next $0.7 \mathrm{~mL}$ of $\mathrm{NaHCO} 3(6 \%)$ were added. The final solution was vortexed and incubated in the dark for $60 \mathrm{~min}$. The solution absorption was measured at $765 \mathrm{~nm}$ in a spectrophotometer (Lambda 25 UV/VIS, Perkin Elmer, Waltham, MA, USA). Blank solution with no extract was used for calibration. Each measurement was compared to a standard curve of gallic acid (GA). The Phe concentration was expressed as mg of GA equivalent $\mathrm{g}^{-1} \mathrm{FW}$.

\subsubsection{Antioxidant Capacity Measurements}

The antioxidant capacity (DPPH) was measured following the method reported by Brand-Williams et al. [25] with minor changes. Firstly, $0.1 \mathrm{~g}$ FW of sample were homogenized in $0.7 \mathrm{~mL}$ of $80 \%$ methanol $(v / v)$, incubated in an ultrasonic bath (Ultrasonic cleaner, Fungilab, Barcelona, Spain) at medium intensity for $30 \mathrm{~min}$, and then vortexed. Samples were centrifuged at $10,000 \mathrm{rpm}$ for $15 \mathrm{~min}$ at $4{ }^{\circ} \mathrm{C}$ and $20 \mu \mathrm{L}$ of the extract were added to $990 \mu \mathrm{L}$ of $0.065 \mathrm{M}$ of 2,2-diphenyl-1-picrylhydrazyl solution (solved in $80 \%$ methanol). The absorbance was measured at $515 \mathrm{~nm}$ against a blank solution $(80 \%$ methanol without extract) after a 30-min reaction at room temperature in the dark using a spectrophotometer (Lambda 25 UV/VIS, Perkin Elmer, Waltham, USA). The results were expressed as the percentage reduction of the initial DPPH absorption in extracts.

\subsection{Mineral Determination}

Samples were dried in a laboratory oven at $65^{\circ} \mathrm{C}$ for $72 \mathrm{~h}$ and homogenized before being burnt in a muffle furnace for $12 \mathrm{~h}$ at $550{ }^{\circ} \mathrm{C}$. Macronutrients and micronutrients were extracted with $5 \mathrm{~mL}$ of $2 \%(v / v)$ nitric acid in an ultrasonic bath for $30 \mathrm{~min}$ at $40{ }^{\circ} \mathrm{C}$. Afterwards, $10 \mathrm{~mL}$ of $2 \%$ nitric acid were added to the solution. Mineral concentrations were measured by ICP emission spectrometry (iCAP 6000, Thermo Scientific, Cambridge, $\mathrm{UK})$. The results for the macro- and micronutrients were expressed as $\mathrm{mg} \mathrm{g}^{-1} \mathrm{DW}$ and $\mu \mathrm{g} \mathrm{g}{ }^{-1} \mathrm{DW}$, respectively.

\subsection{Statistical Analysis}

The results obtained from these determinations were subjected to a one-way analysis of variance (ANOVA) using Statgraphics Centurion XVII (Statistical Graphics Corporation 2014). The statistical analysis was carried out after taking two different factors into account: the variety type and development stage. The results were expressed as mean \pm standard deviation. Means were accepted as being significantly different at a $95 \%$ confidence interval $(p \leq 0.05)$. The mean, maximum and minimum values, coefficient of variation, and F-ratio of all the traits were calculated.

A principal component analysis (PCA) was run for the standardized values using pairwise Euclidean distances among accession means to determine the relations between genotypes in each development stage. The extracted eigenvalues, and the relative and cumulative proportions of total variance explained by the first three principal components (PCs) were calculated. A two-dimensional (2D) scatter plot (first PC vs. second PC) for 
each development stage was prepared based on a distance matrix for the PCs to visualize the relation that explained traits.

By considering the quality traits, three correlation analyses were completed among the varieties, one for each development stage. The individual samples of each accession were subjected to linear regression and correlation coefficients (r) were obtained.

\section{Results}

\subsection{Dry Weight}

Three varieties (CL1, L2, L11) presented no statistical differences in \% DW between the microgreen and adult plants (Figure 2). The highest values were recorded for CL4, L3, and L11 in the microgreen plants (nearly $0.7 \%$ higher than the mean value) and CL5 and L5 in the baby stage (1.8 and 1.1\% higher than the mean value, respectively). L2 and L11 showed the highest DW percentage in the adult stage $(2.3 \%$ and $1.3 \%$ over the mean value, respectively). CL3 and CL5 in the baby and adult stage, respectively, had the lowest percentage of dry biomass (nearly $2.0 \%$ lower than their mean values).

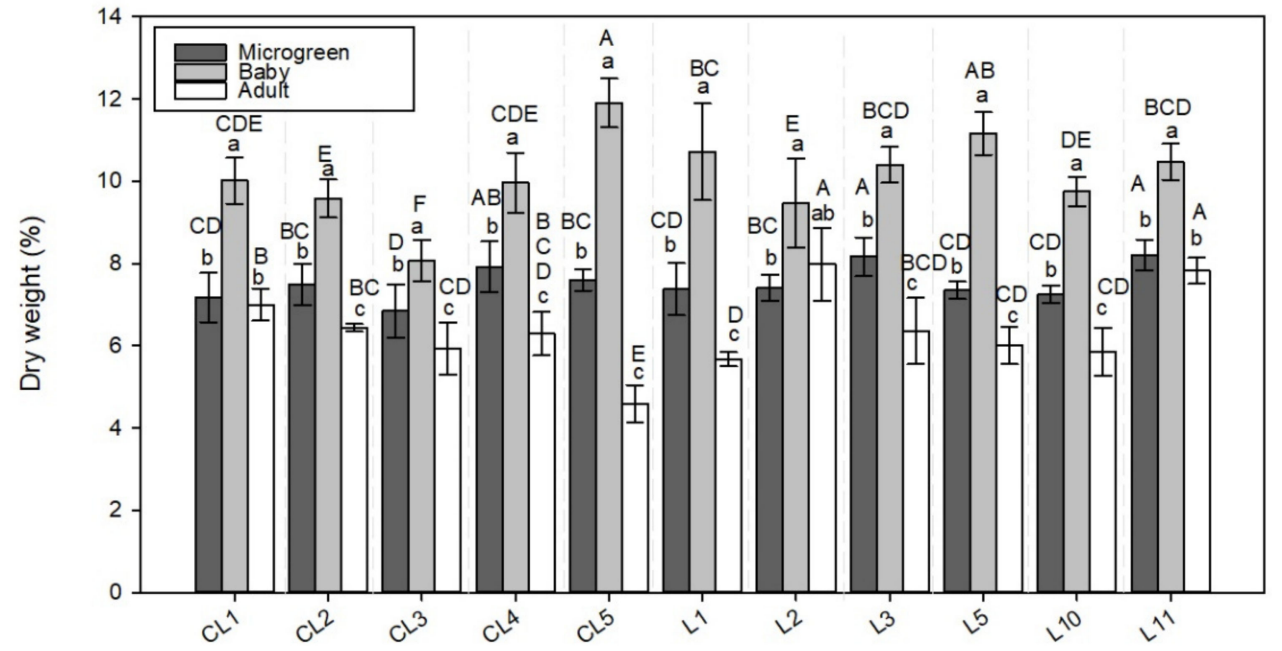

Figure 2. Dry weight (DW) in the 11 lettuce varieties evaluated in the 3 development stages (microgreen, baby, adult). Values are the mean $\pm \mathrm{SE}$ of four replicates per landrace. The mean was subjected to a one-way ANOVA. Different capital and lowercase letters indicate significant differences between varieties and development stages, respectively, at $p<0.05$ by the LSD test.

\subsection{Nutraceutical Compounds and Antioxidant Capacity}

\subsubsection{Total Chlorophyll Concentration}

The highest chlorophyll content (Table 2) was recorded in the baby stage (mean value $27.7 \%$ and $15.8 \%$ higher than microgreens and adults, respectively) in all the varieties but CL2 (Figure 3A), with no significant differences with the adult stage in some varieties (CL3, L1, L2, L3).

In the microgreen stage, landrace L11 had the highest Chl content $(49.9 \%$ over the mean) while the lowest values were shown by L1, L2, and L5 (282.4 $\pm 19.9 \mu \mathrm{g} \mathrm{g}^{-1} \mathrm{FW}$; 23.9\% under the mean value) (Figure 3A).

The highest Chl levels in the baby plants were obtained in CL4, L5, L10, and L11 while CL2 had the lowest values. Adult lettuces L1 and CL5 were highlighted for their highest and lowest Chl contents, respectively.

\subsubsection{Carotenoids}

Table 2 shows the Car content in the different development stages, which was higher in the baby stage than in the other development formats (mean values of $893.5 \%$ and $230.9 \%$ higher than the microgreens and adults, respectively). 
Table 2. Variation parameters for the quality traits in the 11 lettuce varieties evaluated in the 3 development stages (microgreen, baby, adult). Statistics were performed per stage. Values represent the mean, range, coefficient of variation $(\mathrm{CV}, \%)$, F-ratio, and significance $(* * *, * *, *$ indicate significance at $p<0.001, p<0.01, p<0.05)$ for the quality traits. DW: Dry weight; Chl: Chlorophylls; Car: Carotenes; Ant: Anthocyanins; AsA: Ascorbic Acid; Phe: Phenols; DPPH: Antioxidant capacity; Ca: Calcium; K: Potassium; Fe: Iron.

\begin{tabular}{|c|c|c|c|c|c|}
\hline & Unit/Scale & Mean & Range & CV (\%) & F-Ratio \\
\hline \multicolumn{6}{|c|}{ Microgreen } \\
\hline DW & $\%$ & $7.53 \pm 0.59$ & $5.81-8.84^{* * *}$ & 7.84 & 4.81 \\
\hline Chl & $\mu \mathrm{g} \mathrm{g}^{-1} \mathrm{FW}$ & $393.77 \pm 92.38$ & $200.89-647.87^{* * *}$ & 23.46 & 29.45 \\
\hline Car & $\mu \mathrm{g} \mathrm{g}^{-1} \mathrm{FW}$ & $3.70 \pm 9.62$ & $0-43.48^{* * *}$ & 259.62 & 70.10 \\
\hline Ant & $\mu \mathrm{mol} 100 \mathrm{~g}^{-1} \mathrm{FW}$ & $50.67 \pm 10.29$ & $36.12-72.34^{* * *}$ & 20.31 & 20.55 \\
\hline AsA & $\mathrm{mg} 100 \mathrm{~g}^{-1} \mathrm{FW}$ & $61.05 \pm 11.61$ & $34.26-87.01^{* * *}$ & 19.02 & 54.38 \\
\hline Phe & $\mathrm{mg} \mathrm{g}^{-1} \mathrm{DW}$ & $18.69 \pm 5.23$ & $7.43-28.78^{* * *}$ & 28.01 & 24.3 \\
\hline DPPH & $\%$ & $71.52 \pm 21.17$ & $12.65-88.46^{* * *}$ & 29.61 & 32.08 \\
\hline $\mathrm{Ca}$ & $\mathrm{mg} \mathrm{g}^{-1} \mathrm{DW}$ & $9.76 \pm 1.75$ & $6.61-12.81^{* * *}$ & 17.96 & 22.48 \\
\hline K & $\mathrm{mg} \mathrm{g}^{-1} \mathrm{DW}$ & $48.23 \pm 3.93$ & $39.54-60.08^{* *}$ & 8.15 & 2.97 \\
\hline $\mathrm{Fe}$ & $\mu g g^{-1} \mathrm{DW}$ & $225.08 \pm 60.74$ & $68.1-362.18^{* * *}$ & 26.99 & 132.5 \\
\hline \multicolumn{6}{|l|}{ Baby } \\
\hline DW & $\%$ & $10.14 \pm 1.14$ & $7.65-12.74^{* * *}$ & 11.26 & 13.03 \\
\hline Chl & $\mu \mathrm{g} \mathrm{g}^{-1} \mathrm{FW}$ & $502.85 \pm 65.60$ & $339.05-606.61^{* * *}$ & 13.05 & 14.63 \\
\hline Car & $\mu \mathrm{g} \mathrm{g}^{-1} \mathrm{FW}$ & $36.76 \pm 28.89$ & $1.87-126.98^{* * *}$ & 78.6 & 36.93 \\
\hline Ant & $\mu \mathrm{mol} 100 \mathrm{~g}^{-1} \mathrm{FW}$ & $56.16 \pm 29.88$ & $26.46-141.96^{* * *}$ & 56.19 & 296.27 \\
\hline AsA & $\mathrm{mg} 100 \mathrm{~g}^{-1} \mathrm{FW}$ & $58.35 \pm 11.19$ & $39.25-86.49^{* * *}$ & 19.18 & 34.83 \\
\hline Phe & $\mathrm{mg} \mathrm{g}^{-1} \mathrm{DW}$ & $18.43 \pm 8.49$ & $5.58-36.11^{* * *}$ & 46.06 & 45.24 \\
\hline DPPH & $\%$ & $71.07 \pm 13.46$ & $32.61-87.02 * * *$ & 18.93 & 23.79 \\
\hline $\mathrm{Ca}$ & $\mathrm{mg} \mathrm{g}^{-1} \mathrm{DW}$ & $7.23 \pm 1.28$ & $5.39-10.07^{* * *}$ & 17.65 & 7.39 \\
\hline $\mathrm{K}$ & $\mathrm{mg} \mathrm{g}^{-1} \mathrm{DW}$ & $28.18 \pm 3.60$ & $22.21-36.82 *$ & 12.78 & 2.53 \\
\hline $\mathrm{Fe}$ & $\mu \mathrm{g} \mathrm{g}^{-1} \mathrm{DW}$ & $104.64 \pm 18.07$ & $71.24-146.55^{* * *}$ & 17.27 & 4.28 \\
\hline \multicolumn{6}{|l|}{ Adult } \\
\hline DW & $\%$ & $6.48 \pm 1.46$ & $3.83-13.25^{* * *}$ & 22.5 & 6.84 \\
\hline Chl & $\mu \mathrm{g} \mathrm{g}^{-1} \mathrm{FW}$ & $434.36 \pm 46.61$ & $359.85-564.58^{* * *}$ & 10.73 & 7.88 \\
\hline Car & $\mu \mathrm{g} \mathrm{g}^{-1} \mathrm{FW}$ & $11.11 \pm 11.01$ & $0-39.73^{* * *}$ & 99.10 & 35.03 \\
\hline Ant & $\mu \mathrm{mol} 100 \mathrm{~g}^{-1} \mathrm{FW}$ & $47.63 \pm 10.50$ & $29.15-71.76^{* * *}$ & 22.08 & 12.65 \\
\hline AsA & $\mathrm{mg} 100 \mathrm{~g}^{-1} \mathrm{FW}$ & $34.45 \pm 14.33$ & $13.44-64.2^{* * *}$ & 41.58 & 88.68 \\
\hline Phe & $\mathrm{mg} \mathrm{g}^{-1} \mathrm{DW}$ & $3.91 \pm 2.50$ & $0.56-9.38^{* * *}$ & 63.89 & 49.97 \\
\hline DPPH & $\%$ & $15.88 \pm 9.55$ & $3.58-39.41^{* * *}$ & 60.14 & 19.21 \\
\hline $\mathrm{Ca}$ & $\mathrm{mg} \mathrm{g}^{-1} \mathrm{DW}$ & $8.87 \pm 1.79$ & $6.13-13.79^{* * *}$ & 20.18 & 23.04 \\
\hline $\mathrm{K}$ & $\mathrm{mg} \mathrm{g}^{-1} \mathrm{DW}$ & $59.89 \pm 7.66$ & $44.36-75.96^{* * *}$ & 12.80 & 11.55 \\
\hline $\mathrm{Fe}$ & $\mu \mathrm{gg}^{-1} \mathrm{DW}$ & $171.44 \pm 114.32$ & $74.51-514.25^{* * *}$ & 66.68 & 131.98 \\
\hline
\end{tabular}

In the microgreen stage (Figure 3B), 3 of the 11 varieties (CL2, CL5, L11) contained Car compounds, which were not detectable in the other varieties. In the baby stage, all the plants contained Car, which were remarkable in L11 (114.5 $\mathrm{\mu g} \mathrm{g}^{-1} \mathrm{FW}, 210.5 \%$ over the mean value) and also in L10 and 3 commercial varieties (CL1, CL2, CL4) for ranging between 38.5 and $48.9 \mu \mathrm{g} \mathrm{g}^{-1}$ FW. Of the adult lettuces, CL4 and L10 showed the highest Car level, which was not detectable in three varieties: CL3, L1, and L2.

\subsubsection{Anthocyanins}

One detected trend was that the highest Ant content was observed in the commercial varieties and landraces in the microgreen stage (mean values of 50.7 and $56.2 \mu \mathrm{mol} 100 \mathrm{~g}^{-1}$ FW, respectively, Table 2), expect in CL4, L10, and L11, which showed higher contents in the baby and adult stages (Figure 3C). 
A

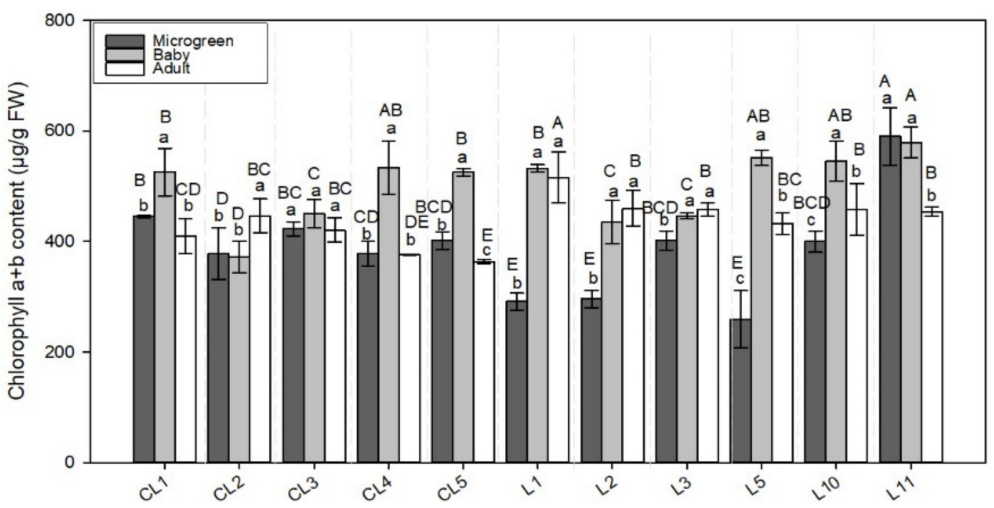

B

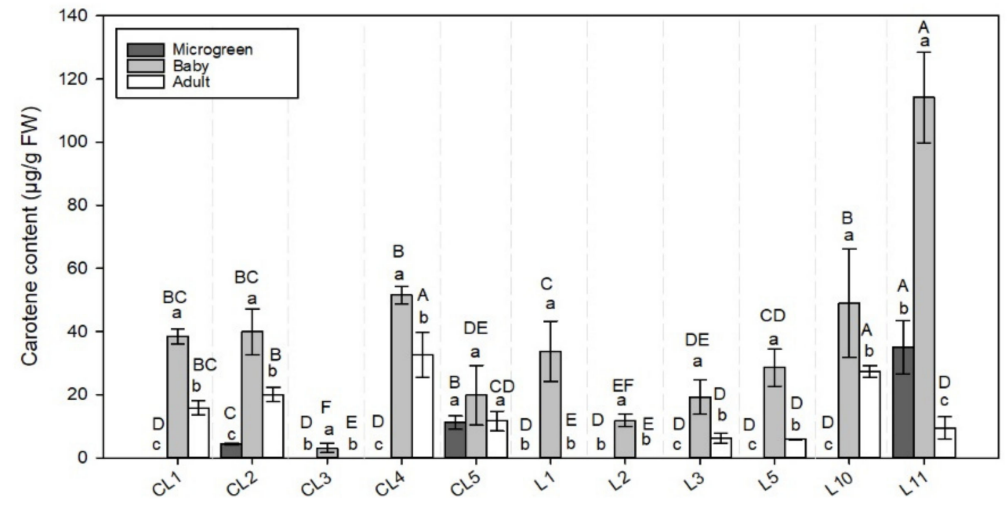

C

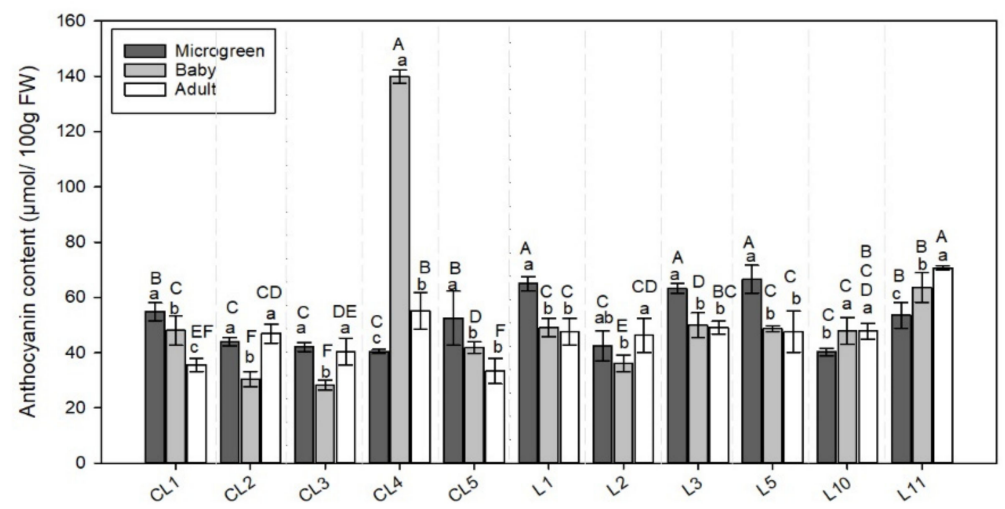

Figure 3. The (A) chlorophyll $\mathrm{a}+\mathrm{b}(\mathrm{Chl})$, (B) carotenoid (Car), and (C) anthocyanin (Ant) concentrations in the 11 lettuce varieties evaluated in the 3 development stages (microgreen, baby, adult). Values are the mean \pm SE of four replicates per landrace. The mean was subjected to a one-way ANOVA. Different capital and lowercase letters indicate significant differences between varieties and development stages, respectively, at $p<0.05$ by the LSD test. FW: Fresh weight.

Of the microgreens, 3 local landraces (L1, L3, L5) stood out for their high $(64.9 \pm 1.7 \mu \mathrm{mol}$ $100 \mathrm{~g}^{-1} \mathrm{FW}$, Figure 3C). In the baby stage, Ant levels were notably elevated in CL4 (148.9\% higher than the mean value) and low in CL2 and CL3 (nearly 45\% lower than the mean). Of all the adult plants, L11 had the highest Ant content (48.33\% over the mean) and CL5 has the lowest content (29.94\% under the mean).

\subsubsection{Ascorbic Acid}

The maximum AsA concentration appeared in the microgreen and baby stages (Table 2), and L11 presented the highest AsA levels (34.8\% and 39.1\% higher than the mean value for both stages, respectively) (Figure 4A). CL4 also had a high AsA level in the baby stage. The AsA concentration in adult lettuce (mean value $34.45 \mathrm{mg} 100 \mathrm{~g}^{-1} \mathrm{FW}$, Table 2) dropped 
in both the commercial and local landraces, with the lowest values shown for CL5 (53.8\% lower than the mean). The highest AsA content in the adult stage was observed in lettuces CL4 and L11 (70.7\% and 77.0\% higher than the mean value, respectively).

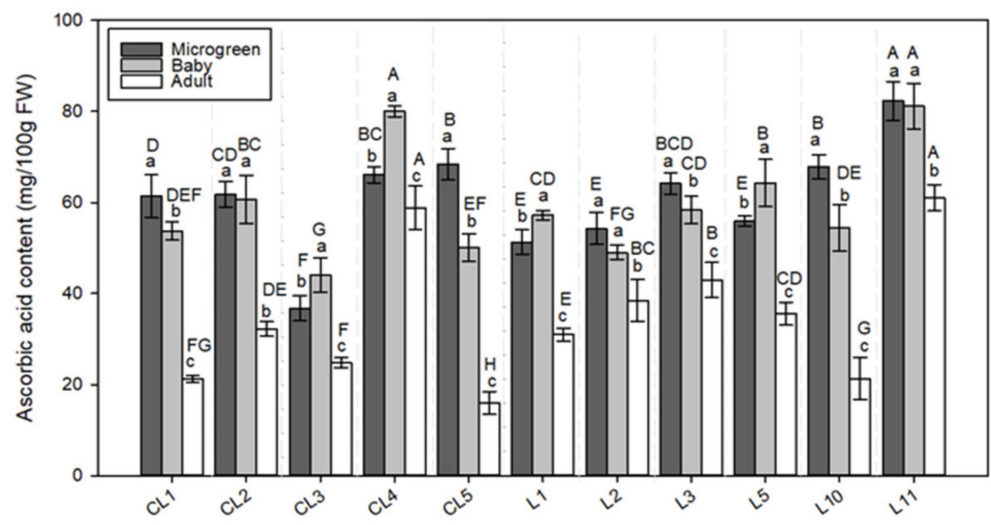

B
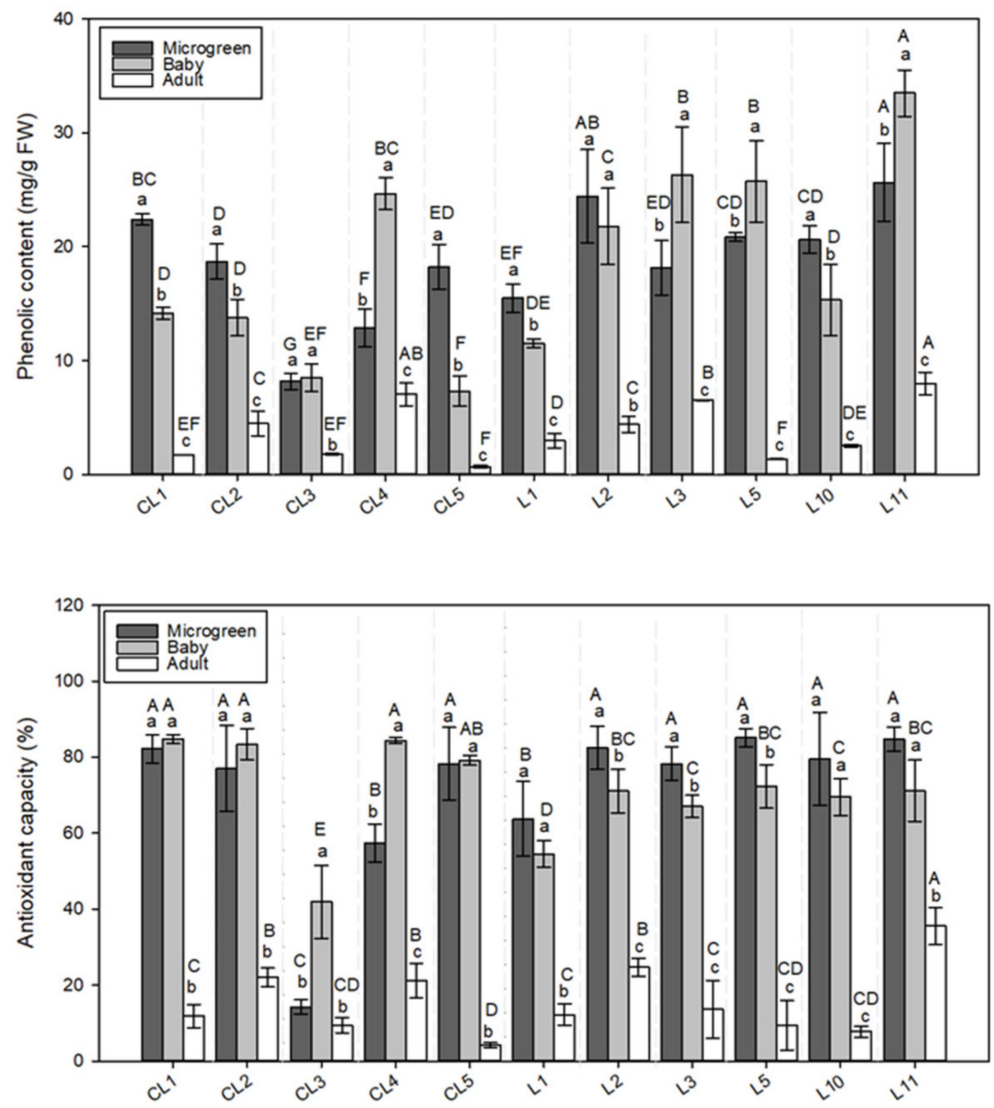

Figure 4. The (A) ascorbic acid (AsA), (B) phenols (Phe), and (C) antioxidant (DPPH) capacity of 11 lettuce varieties evaluated in 3 development stages (microgreen, baby, adult). Values are the mean \pm SE of four replicates per landrace. The mean was subjected to a one-way ANOVA. Different capital and lowercase letters indicate significant differences between varieties and development stages, respectively, at $p<0.05$ by the LSD test. FW: Fresh weight.

\subsubsection{Phenols}

The mean Phe content (Table 2) was similar in the microgreen and baby stages, and was around 79\% higher than in adult lettuces. Two landraces (L2 and L11) stood out for their high Phe content in the microgreen stage (around $25.0 \mathrm{mg} \mathrm{g}^{-1} \mathrm{FW}$ ) (Figure 4B). In the baby stage, the most remarkable varieties were CL4 and local landraces L3 and L5, especially L11 (between 24.7 and $33.5 \mathrm{mg} \mathrm{g}^{-1} \mathrm{FW}$ ). CL3 had the lowest Phe content in both 
the microgreen and baby stages (56.3\% and 53.9\% lower than the mean, respectively). The highest Phe content in the adult stage was observed in the lettuces CL4 and L11 (79.8\% and $104.1 \%$ higher than the mean value, respectively). In total, 3 of the 5 commercial varieties (CL1, CL3, CL5) showed very low Phe contents in the adult stage (from 0.7 to $\left.1.8 \mathrm{mg} \mathrm{g}^{-1} \mathrm{FW}\right)$, which occurred in only 1 local landrace: L5 with $1.4 \mathrm{mg} \mathrm{g}^{-1} \mathrm{FW}$.

\subsubsection{Antioxidant Capacity}

Similar to the AsA and Phe contents, the greatest DPPH activities in the commercial varieties and landraces appeared in the microgreen and baby development stages (mean values of $71.5 \%$ and $71.1 \%$, respectively, Table 2), expect in CL3, which was higher only in the baby stage. No significant differences between the microgreen and adult stages were found (Figure $4 \mathrm{C}$ ). A lower antioxidant capacity was measured in the adult stage (around $55.6 \%$ lower than in the other two stages, Table 2).

When comparing the varieties across their different development formats, the highest DPPH levels in the microgreen lettuces were observed for 8 of the 11 varieties, except CL3, CL4, and L1 (Figure 4C). In this stage, most local landraces presented between $6.8 \%$ and $13.6 \%$ more DPPH activity than the mean (71.5\%), and slightly lower activity was observed for L1 only $(7.8 \%)$.

In the baby stage, the lowest DPPH was displayed in CL3 and L1 (29.1\% and 16.5\% lower than the mean, respectively). In the adult stage (mean value $15.9 \%$, Table 2 ), the greatest activity was observed in L11 (19.7\% higher than the mean value), with a significant difference $(p<0.05)$.

\subsection{Mineral Concentration}

Table 3 shows the concentration of three of the main minerals $(\mathrm{Ca}, \mathrm{K}, \mathrm{Fe}$ ) related to lettuce's nutritional quality. The results for the other macro- and micronutrients are shown in Supplementary Table S1.

The maximum Ca concentration was found in the microgreen stage in all the varieties (Table 2) but L11, which was exceeded by adult lettuce. Of the varieties, 4 of the 6 local landraces (L2, L5, L10, L11) and 1 commercial lettuce (CL3) in the microgreen stage obtained the highest $\mathrm{Ca}$ concentrations (between 10.28 and $12.38 \mathrm{mg} \mathrm{g}-1 \mathrm{DW}$, Table 3) while the lowest value was shown by L1 (26.42\% lower than mean value, Table 2$)$. In the baby stage, the most remarkable varieties were CL3, CL4, L4, L5, L10, and L11 (between 7.76 and $\left.8.89 \mathrm{mg} \mathrm{g}^{-1} \mathrm{DW}\right)$. The Ca content in adults was also high in CL4 and two other local landraces (L1 and L3).

As a general trend, the adult stage presented the highest $\mathrm{K}$ concentration, followed by microgreens, with the lowest levels observed in the baby stage (52.15\% and $41.57 \%$ lower than the previous ones, respectively) (Table 2). The highest $\mathrm{K}$ concentrations in microgreens were obtained for CL3, CL5, L3, L5, and L10 (between 48.9 and $53.6 \mathrm{mg} \mathrm{g}^{-1}$ DW, Table 3). The highest $\mathrm{K}$ levels in the baby stage were observed in the varieties CL3, CL4, and L2 (between 30.3 and $32.5 \mathrm{mg} \mathrm{g}^{-1} \mathrm{DW}$ ). In the adult stage, 2 commercial varieties (CL2 and CL3) and 2 local landraces (L1 and L3) stood out for their high K contents (between 66.0 and $68.7 \mathrm{mg} \mathrm{g}^{-1} \mathrm{DW}$ ).

Another trend that was observed was the lowest Fe concentrations, which were recorded in the baby stage (mean value 53.5\% and 39.0\% lower than the microgreen and adult stages, respectively, Table 2). Depending on the variety, the highest significant Fe levels (Table 3) were obtained in the microgreen stage (CL1, CL2, CL5, L2, and L3), adult stage (CL3, CL4, and L11), or both (L1, L5, and L10). Of the microgreens, the varieties L2 and CL3 presented the highest and lowest Fe concentrations (344.9 and $77.7 \mu \mathrm{g} \mathrm{g}^{-1}$ DW, respectively, Table 3). In the baby stage, the Fe concentration was more homogeneous (low CV\%, Table 2) and 5 of the 11 varieties (CL1, CL3, CL4, L2, and L11) showed top levels (between 114.7 and $122.5 \mu \mathrm{g} \mathrm{g}^{-1} \mathrm{DW}$ ). The highest Fe concentration in adult lettuces was observed in local landrace L11 (187.8\% higher than the mean adult value, Table 2). IIn total, 
3 commercial varieties and 1 local variety (CL1, CL2, CL5, and L3) presented the lowest Fe level in the adult stage (between $50.8 \%$ and $35.8 \%$ lower than the mean).

Table 3. The calcium (Ca), potassium (K), and iron (Fe) concentrations of 11 lettuce varieties evaluated in 3 development stages (microgreen, baby, adult). Values are the mean $\pm \mathrm{SE}$ of four replicates per variety. The means were subjected to a one-way ANOVA analysis. Different capital and lowercase letters indicate significant differences between varieties and development stages, respectively, at $p<0.05$ using the LSD test. DW: Dry weight.

\begin{tabular}{|c|c|c|c|c|c|c|c|}
\hline \multirow{2}{*}{$\begin{array}{c}\text { Variety } \\
\text { CL1 }\end{array}$} & \multirow{4}{*}{$\begin{array}{c}\text { State } \\
\text { Microgreen } \\
\text { Baby } \\
\text { Adult }\end{array}$} & \multicolumn{2}{|c|}{$\mathrm{Ca}\left(\mathrm{mg} \mathrm{g}^{-1} \mathrm{DW}\right)$} & \multicolumn{2}{|c|}{$\mathrm{K}\left(\mathrm{mg} \mathrm{g}^{-1} \mathrm{DW}\right)$} & \multicolumn{2}{|c|}{$\mathrm{Fe}\left(\mu \mathrm{g} \mathrm{g}^{-1} \mathrm{DW}\right)$} \\
\hline & & $8.76 \pm 0.87$ & $\mathrm{DEFa}$ & $48.06 \pm 1.26$ & $\mathrm{Bb}$ & $230.48 \pm 20.05$ & $\mathrm{CDa}$ \\
\hline & & $5.64 \pm 0.16$ & $\mathrm{Cc}$ & $26.47 \pm 3.03$ & CDc & $119.34 \pm 16.77$ & $\mathrm{Ab}$ \\
\hline & & $7.21 \pm 0.03$ & $\mathrm{~Eb}$ & $58.13 \pm 2.63$ & $\mathrm{Ca}$ & $108.80 \pm 7.19$ & $\mathrm{DEb}$ \\
\hline \multirow[t]{3}{*}{ CL2 } & Microgreen & $8.66 \pm 0.54$ & $\mathrm{DEFa}$ & $45.85 \pm 4.56$ & $\mathrm{BCb}$ & $230.51 \pm 2.06$ & $\mathrm{CDa}$ \\
\hline & Baby & $6.65 \pm 0.82$ & $\mathrm{BCb}$ & $25.37 \pm 3.35$ & Dc & $92.90 \pm 9.12$ & $\mathrm{Cb}$ \\
\hline & Adult & $7.19 \pm 0.17$ & $\mathrm{~Eb}$ & $68.73 \pm 4.84$ & $\mathrm{Aa}$ & $84.30 \pm 10.40$ & $\mathrm{~Eb}$ \\
\hline \multirow[t]{3}{*}{ CL3 } & Microgreen & $10.91 \pm 1.35$ & $\mathrm{Ba}$ & $53.59 \pm 4.36$ & $\mathrm{Ab}$ & $77.74 \pm 10.88$ & $\mathrm{~Gb}$ \\
\hline & Baby & $7.93 \pm 0.82$ & $\mathrm{Ab}$ & $32.53 \pm 2.61$ & Ac & $114.69 \pm 8.51$ & $\mathrm{ABb}$ \\
\hline & Adult & $8.76 \pm 0.65$ & $\mathrm{CDb}$ & $66.02 \pm 4.46$ & $\mathrm{ABa}$ & $218.88 \pm 38.54$ & $\mathrm{Ba}$ \\
\hline \multirow[t]{3}{*}{ CL4 } & Microgreen & $9.66 \pm 1.29$ & $\mathrm{Ca}$ & $47.14 \pm 2.89$ & $\mathrm{Bb}$ & $155.56 \pm 4.73$ & $\mathrm{Fb}$ \\
\hline & Baby & $7.76 \pm 0.47$ & $\mathrm{Ab}$ & $31.86 \pm 1.87$ & $\mathrm{ABc}$ & $118.73 \pm 6.45$ & $\mathrm{Ab}$ \\
\hline & Adult & $11.07 \pm 0.70$ & $\mathrm{Ba}$ & $57.91 \pm 6.47$ & $\mathrm{Ca}$ & $193.38 \pm 12.79$ & $\mathrm{Ba}$ \\
\hline \multirow[t]{3}{*}{ CL5 } & Microgreen & $8.21 \pm 0.23$ & $\mathrm{EFa}$ & $48.92 \pm 3.79$ & $\mathrm{ABa}$ & $255.54 \pm 12.62$ & $\mathrm{Ba}$ \\
\hline & Baby & $5.88 \pm 0.46$ & $\mathrm{Cc}$ & $26.46 \pm 2.02$ & $\mathrm{CDb}$ & $94.77 \pm 16.44$ & $\mathrm{Cb}$ \\
\hline & Adult & $6.82 \pm 0.61$ & $\mathrm{~Eb}$ & $46.21 \pm 1.68$ & $\mathrm{Da}$ & $110.06 \pm 22.83$ & $\mathrm{DEb}$ \\
\hline \multirow[t]{3}{*}{ L1 } & Microgreen & $7.72 \pm 0.58$ & $\mathrm{Fa}$ & $48.73 \pm 4.69$ & $\mathrm{Bb}$ & $216.87 \pm 8.87$ & $\mathrm{DEa}$ \\
\hline & Baby & $6.23 \pm 0.55$ & $\mathrm{Cb}$ & $27.89 \pm 1.65$ & BCDc & $91.43 \pm 13.50$ & $\mathrm{Cb}$ \\
\hline & Adult & $7.51 \pm 0.83$ & $\mathrm{Ea}$ & $66.53 \pm 5.29$ & $\mathrm{ABa}$ & $123.30 \pm 10.28$ & $\mathrm{CDab}$ \\
\hline \multirow[t]{3}{*}{ L2 } & Microgreen & $12.37 \pm 0.15$ & $\mathrm{Aa}$ & $47.69 \pm 0.86$ & $\mathrm{Ba}$ & $344.91 \pm 13.64$ & $\mathrm{Aa}$ \\
\hline & Baby & $8.89 \pm 1.02$ & $\mathrm{Ab}$ & $30.25 \pm 5.41$ & $\mathrm{ABCb}$ & $119.75 \pm 20.78$ & $\mathrm{Aa}$ \\
\hline & Adult & $9.47 \pm 0.71$ & $\mathrm{CDb}$ & $50.63 \pm 1.14$ & $\mathrm{Da}$ & $119.34 \pm 3.73$ & $\mathrm{Db}$ \\
\hline \multirow[t]{3}{*}{ L3 } & Microgreen & $7.77 \pm 0.79$ & EFab & $49.18 \pm 3.43$ & $\mathrm{ABb}$ & $244.98 \pm 3.66$ & $\mathrm{BCDa}$ \\
\hline & Baby & $6.50 \pm 1.03$ & $\mathrm{Cb}$ & $28.21 \pm 5.60$ & $\mathrm{ABCDC}$ & $98.21 \pm 5.05$ & $\mathrm{BCb}$ \\
\hline & Adult & $8.78 \pm 0.73$ & $\mathrm{CDa}$ & $66.10 \pm 4.57$ & $\mathrm{ABa}$ & $100.87 \pm 13.03$ & $\mathrm{DEb}$ \\
\hline \multirow[t]{3}{*}{ L5 } & Microgreen & $12.38 \pm 0.23$ & $\mathrm{Aa}$ & $49.73 \pm 2.88$ & $\mathrm{ABb}$ & $222.59 \pm 9.10$ & $\mathrm{DEa}$ \\
\hline & Baby & $8.58 \pm 1.18$ & $\mathrm{Ab}$ & $25.48 \pm 0.46$ & Dc & $89.74 \pm 13.70$ & $\mathrm{Cb}$ \\
\hline & Adult & $9.70 \pm 1.01$ & $\mathrm{Cb}$ & $59.69 \pm 4.42$ & $\mathrm{Ca}$ & $153.94 \pm 27.85$ & $\mathrm{Cab}$ \\
\hline \multirow[t]{3}{*}{ L10 } & Microgreen & $10.66 \pm 0.15$ & $\mathrm{BCa}$ & $49.57 \pm 1.33$ & $\mathrm{ABb}$ & $208.97 \pm 2.41$ & Eab \\
\hline & Baby & $7.77 \pm 0.68$ & $\mathrm{ABb}$ & $26.68 \pm 1.41$ & CDc & $88.93 \pm 12.13$ & $\mathrm{Cb}$ \\
\hline & Adult & $8.65 \pm 0.92$ & $\mathrm{Db}$ & $56.93 \pm 4.46$ & $\mathrm{Ca}$ & $152.15 \pm 19.59$ & $\mathrm{Cb}$ \\
\hline \multirow[t]{3}{*}{ L11 } & Microgreen & $10.28 \pm 0.12$ & $\mathrm{BCb}$ & $42.13 \pm 2.81$ & $\mathrm{Cb}$ & $236.34 \pm 9.73$ & $\mathrm{BCDb}$ \\
\hline & Baby & $8.07 \pm 1.09$ & Ac & $28.77 \pm 2.17$ & $\mathrm{ABCDC}$ & $122.49 \pm 17.73$ & $\mathrm{Ab}$ \\
\hline & Adult & $12.41 \pm 0.92$ & $\mathrm{Aa}$ & $61.91 \pm 1.62$ & $\mathrm{BCa}$ & $493.47 \pm 23.01$ & $\mathrm{Aa}$ \\
\hline
\end{tabular}

\subsection{PCA Analysis}

The PCA and eigenvalues higher than 1 reflected a different pattern in the correlation of lettuces in the three development stages (Table 4). In all cases, there were 3 significant PCs that described around $83 \%, 75 \%$, and $76 \%$ of the variability between varieties in the microgreen, baby, and adult stages, respectively.

In microgreens, the first, second, and third PCs accounted for $46.9 \%, 22.8 \%$, and $13.5 \%$ of the total variation of the studied traits, respectively. The first PC correlated positively with all the traits, except for a negative correlation with the K concentration $(-0.409)$, and the AsA concentration had the highest value (0.419). When analyzing the second 
PC, the highest positive correlation was recorded for the Fe mineral (0.435), with negative correlations observed for Chl and Car ( -0.557 and -0.294 , respectively).

Table 4. Correlation coefficients for the quality traits of the 3 first principal components, eigenvalue, and the relative and cumulative proportions of the total variance explained by these components, in 11 lettuce varieties evaluated in 3 development stages (microgreen, baby, adult). DW: Dry weight; Chl: Chlorophylls; Car: Carotenoids; Ant: Anthocyanins; AsA: Ascorbic Acid; Phe: Phenols; DPPH: Antioxidant capacity; Ca: Calcium; K: Potassium; Fe: Iron.

\begin{tabular}{|c|c|c|c|}
\hline & First PC & Second PC & Third PC \\
\hline \multicolumn{4}{|l|}{ Microgreen } \\
\hline DW & 0.355 & -0.230 & \\
\hline Chl $a+b$ & 0.203 & -0.557 & \\
\hline Car & 0.334 & -0.294 & 0.213 \\
\hline Ant & & & -0.665 \\
\hline AsA & 0.419 & & \\
\hline Phe & 0.366 & 0.352 & \\
\hline $\mathrm{DPPH}$ & 0.373 & 0.346 & \\
\hline $\mathrm{Ca}$ & & 0.270 & 0.653 \\
\hline $\mathrm{K}$ & -0.409 & & -0.182 \\
\hline $\mathrm{Fe}$ & 0.295 & 0.435 & \\
\hline Eigenvalue & 4.70 & 2.28 & 1.35 \\
\hline Variance explained (\%) & 46.99 & 22.80 & 13.49 \\
\hline Cumulative variance explained (\%) & 46.99 & 69.79 & 83.28 \\
\hline \multicolumn{4}{|l|}{ Baby } \\
\hline DW & 0.201 & -0.471 & \\
\hline Chl $a+b$ & 0.292 & & 0.509 \\
\hline Car & 0.459 & & 0.221 \\
\hline Ant & 0.335 & & -0.545 \\
\hline AsA & 0.510 & & \\
\hline Phe & 0.413 & 0.167 & 0.180 \\
\hline DPPH & 0.284 & -0.269 & -0.466 \\
\hline $\mathrm{Ca}$ & & 0.403 & 0.292 \\
\hline K & & 0.553 & -0.153 \\
\hline $\mathrm{Fe}$ & 0.169 & 0.436 & -0.179 \\
\hline Eigenvalue & 3.46 & 2.64 & 1.39 \\
\hline Variance explained (\%) & 34.60 & 26.43 & 13.90 \\
\hline Cumulative variance explained (\%) & 34.60 & 61.02 & 74.93 \\
\hline \multicolumn{4}{|l|}{ Adult } \\
\hline DW & 0.328 & & -0.326 \\
\hline $\mathrm{Chl} \mathrm{a}+\mathrm{b}$ & -0.360 & & \\
\hline Car & & 0.593 & -0.415 \\
\hline Ant & 0.331 & -0.270 & 0.242 \\
\hline AsA & 0.396 & 0.157 & \\
\hline Phe & 0.369 & 0.334 & \\
\hline DPPH & 0.406 & & \\
\hline $\mathrm{Ca}$ & 0.248 & -0.428 & -0.218 \\
\hline K & & 0.388 & 0.718 \\
\hline $\mathrm{Fe}$ & 0.313 & -0.289 & 0.283 \\
\hline Eigenvalue & 5.09 & 1.44 & 1.07 \\
\hline Variance explained (\%) & 50.88 & 14.40 & 10.73 \\
\hline Cumulative variance explained (\%) & 50.88 & 65.27 & 76.00 \\
\hline
\end{tabular}

In the baby stage, the relevance of the first PC was less than in the other 2 stages and accounted for only $34.6 \%$ of the total variation. The second and third PCs accounted for $26.4 \%$ and $13.9 \%$ of the variability, respectively. Regarding the correlation values in 
the first PC, all the traits were positively correlated, and the most significant results were obtained for the Car, Phe, and AsA concentrations. The highest positive correlations in the second PC corresponded to the mineral contents ( $\mathrm{Ca}, \mathrm{K}$, and $\mathrm{Fe}$ ) while DW was negatively correlated $(-0.471)$.

The distribution of the adult lettuces in the PCA was determined mostly by the variability of the traits in the first PC (50.9\%) while the second and third PCs represented only $14.4 \%$ and $10.7 \%$ of the variation, respectively. Most traits presented a moderate positive correlation of the first PC, and DPPH, Phe, and AsA had the highest values (between 0.406 and 0.369). A moderate value was also obtained for the negative correlation $(-0.360)$ with the Chl content of the first PC. When analyzing the second PC, the highest positive correlation was for observed for the Car concentration (0.593) while the most negative value was shown by the Ca content $(-0.428)$.

For the three development stages, the projection on the PCA plot for the first and second PCs (Figure 5) showed a similar pattern of spread over the area. In general terms, there was a group with a large number of varieties located in the central zone of the graphs while two or three varieties were located further to the right or the left of the plots.

A
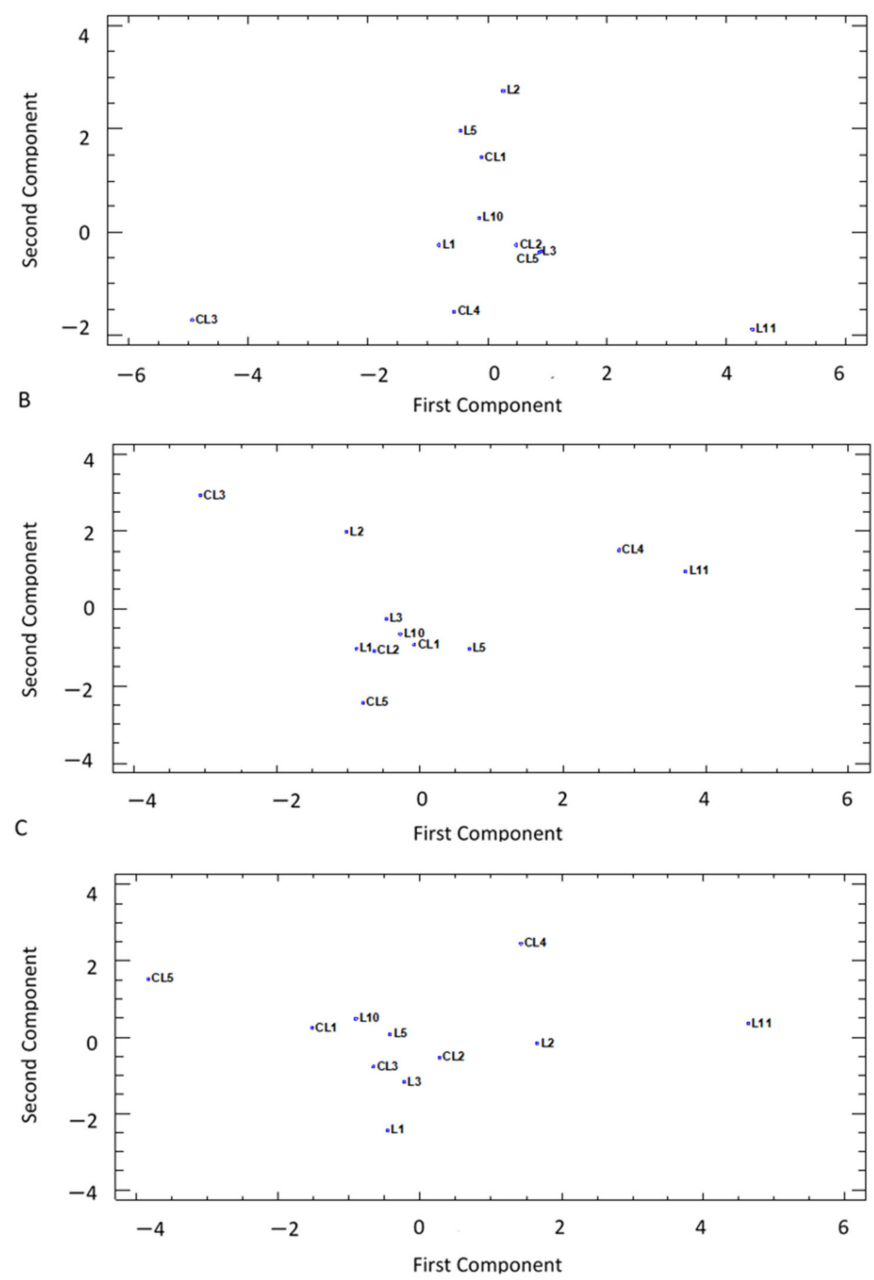

Figure 5. Principal component analysis (PCA) of 11 lettuce varieties based on quality traits represented in the 2 first components of the PCA for the (A) microgreen stage (46.99\% and $22.80 \%$ of the Tables 3 and $4.60 \%$ and $26.43 \%$ of the total variation, respectively), and (C) adult stage (50.88\% and $14.44 \%$ of the total variation, respectively).

In microgreens, the highest value was recorded for the first PC (right zone) for landrace L11 (Figure 5A) and its top levels correlated with four traits: Car, AsA, Phe, and DPPH 
(Figures 3B and 4A-C) and low K levels (Table 3). On the contrary, the lowest values for AsA, DPPH, and Phe throughout the experiment meant the variety CL3 was located further to the left of the plot. For the second PC, local landrace L2 was located at the top of the plot due to its high Fe content (Table 3) and low Chl concentration (Figure 3A) while L11 was located at the bottom due to its high pigments concentration (Chl and Car, Figure 3A,B). The low Fe level in CL3 and CL4 (Table 3) also placed these two commercial varieties in the lower graph area (Figure 5A).

In the baby stage, L11 was located on the right (Figure 5A) due to its high levels of Car (Figure 3B), AsA, and Phe (Figure 4A,B). CL4 also presented good Car and AsA levels. The lowest Car, AsA, and Phe concentrations in the experiment observed for lettuce CL3 placed this commercial variety further to the left in the plot. For the second PC, these 3 varieties together with L2 were placed at the top of the plot due to their significant concentrations of minerals ( $\mathrm{Ca}, \mathrm{K}$, and Fe, Table 3), and CL3 also presented the lowest dry biomass percentage in the baby stage (Figure 2). In contrast, the high DW value of CL5, together with a low mineral content, meant that this commercial variety was located at the bottom of the plot.

L11 in the adult stage once again presented the highest AsA, Phe, and DPPH levels, and it was located further to the right in Figure 5C, followed by CL4 and L2, which displayed significant levels for these traits. Unlike the other 2 stages, the variety further to the right in the adult format was CL5, which presented the lowest AsA content throughout the experiment, together with low Phe and DPPH levels (Figure 4A-C). According to the second PC, the most remarkable variety was CL4 (top of the plot), which occupied first and second places regarding the Phe and Car contents. L1 (bottom of the plot) also presented one of the lowest Car concentrations during the experiment in the adult stage.

\subsection{Correlation between Quality Compounds}

Correlation analyses were carried out to estimate the relation between the most important quality traits in the three development stages (Table 5).

Among the microgreens, the pairwise coefficients showed a positive correlation and a statistical significance for 6 out of the 36 studied pairs of traits. The most representative positive relations were observed between Phe and DPPH $(r=0.721)$ and Car and AsA $(\mathrm{r}=0.505)$. Statistically significant negative correlations were also observed for 4 of the 45 studied pairs of traits. The closest negative relations were observed for $\mathrm{K}$ vs. Fe concentrations $(\mathrm{r}=-0.604)$ and $\mathrm{K}$ vs. Car $(\mathrm{r}=-0.494)$.

Table 5. Linear correlation coefficient ( $r)$ and its significance of the quality traits in the 11 lettuce varieties evaluated in 3 development stages (microgreen, baby, adult). ${ }^{* *},{ }^{* *}, *$ indicate significance at $p<0.001, p<0.01, p<0.05$ for r. Chl: Chlorophylls; Car: Carotenoids; Ant: Anthocyanins; AsA: Ascorbic Acid; Phe: Phenols; DPPH: Antioxidant capacity; Ca: Calcium; K: Potassium; Fe: Iron.

\begin{tabular}{|c|c|c|c|c|c|c|c|c|c|}
\hline \multicolumn{10}{|l|}{ Microgreen } \\
\hline & Chl $a+b$ & Car & Ant & AsA & Phe & DPPH & $\mathrm{Ca}$ & $\mathbf{K}$ & $\mathbf{F e}$ \\
\hline $\mathrm{Chl} a+b$ & & 0.4143 * & -0.0364 & 0.3928 * & 0.0747 & 0.0346 & -0.117 & -0.119 & -0.0901 \\
\hline Car & & & 0.0732 & $0.5045^{* *}$ & 0.1708 & 0.2554 & -0.1941 & $\begin{array}{c}-0.4941 \\
* *\end{array}$ & 0.2132 \\
\hline Ant & & & & 0.0124 & 0.2169 & 0.1641 & $\begin{array}{c}-0.4458 \\
* *\end{array}$ & -0.1202 & 0.2338 \\
\hline AsA & & & & & 0.3244 * & $0.4498^{* *}$ & -0.1398 & -0.3722 * & 0.1853 \\
\hline Phe & & & & & & $0.7212^{* * *}$ & 0.262 & -0.2496 & 0.2812 \\
\hline DPPH & & & & & & & 0.1729 & -0.1802 & 0.1598 \\
\hline $\mathrm{Ca}$ & & & & & & & & 0.0285 & 0.0943 \\
\hline K & & & & & & & & & $-0.604^{* * *}$ \\
\hline $\mathrm{Fe}$ & & & & & & & & & \\
\hline
\end{tabular}


Table 5. Cont.

\begin{tabular}{|c|c|c|c|c|c|c|c|c|c|}
\hline \multicolumn{10}{|l|}{ Baby } \\
\hline & Chl $a+b$ & Car & Ant & AsA & Phe & DPPH & $\mathrm{Ca}$ & $\mathbf{K}$ & $\mathrm{Fe}$ \\
\hline Chl $a+b$ & & 0.5116 ** & 0.2391 & 0.3653 * & 0.27 & 0.0557 & 0.0786 & 0.0099 & 0.0448 \\
\hline Car & & & 0.271 & $0.6154^{* * *}$ & $0.4764^{* *}$ & 0.2258 & 0.1565 & -0.0187 & $0.4546^{* *}$ \\
\hline Ant & & & & $0.6243^{* * *}$ & 0.2022 & $0.4963^{* * *}$ & -0.0116 & 0.1843 & 0.116 \\
\hline AsA & & & & & $0.6974^{* * *}$ & $0.4557^{* *}$ & 0.1692 & -0.0295 & 0.3639 * \\
\hline Phe & & & & & & 0.184 & 0.3394 * & 0.0149 & 0.3192 * \\
\hline DPPH & & & & & & & -0.1262 & -0.2486 & 0.0874 \\
\hline $\mathrm{Ca}$ & & & & & & & & 0.4761 ** & 0.1332 \\
\hline K & & & & & & & & & 0.2664 \\
\hline \multicolumn{10}{|l|}{$\mathrm{Fe}$} \\
\hline \multicolumn{10}{|l|}{ Adult } \\
\hline & Chl $a+b$ & Car & Ant & AsA & Phe & DPPH & $\mathrm{Ca}$ & $\mathbf{K}$ & Fe \\
\hline $\mathrm{Chl} \mathrm{a}+\mathrm{b}$ & & -0.3158 & 0.3714 * & 0.2159 & 0.1143 & 0.2218 & 0.0939 & $0.419^{* *}$ & -0.0149 \\
\hline Car & & & 0.15 & 0.0572 & 0.2014 & 0.0254 & 0.147 & -0.0818 & 0.0858 \\
\hline Ant & & & & $0.5291^{* * *}$ & $0.4224 * *$ & $0.5695^{* * *}$ & $0.5614^{* * *}$ & 0.2667 & $0.584^{* * *}$ \\
\hline AsA & & & & & $0.8672 * * *$ & $0.7029 * * *$ & $0.7997^{* * *}$ & 0.2131 & $0.5939^{* * *}$ \\
\hline Phe & & & & & & $0.7243^{* * *}$ & $0.6467^{* * *}$ & 0.1911 & $0.5194^{* * * *}$ \\
\hline DPPH & & & & & & & $0.5732^{* * *}$ & 0.0936 & $0.5226^{* * *}$ \\
\hline $\mathrm{Ca}$ & & & & & & & & 0.0815 & $0.7591^{* * *}$ \\
\hline K & & & & & & & & & 0.0814 \\
\hline $\mathrm{Fe}$ & & & & & & & & & \\
\hline
\end{tabular}

In the baby stage, the number of positive correlations rose to 13 and the strongest coefficients were observed for AsA vs. Car, AsA vs. Ant, and Asa vs. Phe (r between 0.615 and 0.697).

All significant pairwise coefficients in the adult lettuces showed positive correlations, including 17 of the 36 studied pairs of traits. The most representative relations were observed between the several Ant, AsA, Phe, and DPPH combinations, with the highest values observed for the pairs AsA vs. Phe, AsA vs. DPPH, and Phe vs. DPPH (r between 0.867 and 0.703 ). Important relations ( $r$ between 0.519 and 0.799 ) were observed for minerals (Ca and Fe) and several quality traits (Ant, AsA, Phe, and DPPH).

\section{Discussion}

Although lettuce is particularly known for its high water percentage and low calorie content [5], as it is generally consumed and marketed whole and raw [26], more nutrients are preserved than in other cooked or processed vegetables. Thus, its nutritional benefits related to its dietary fiber, mineral and vitamin contents, and several bioactive compounds, such as carotenoids and phenolic compounds, remain [5].

As several authors, such as Mou [27], Kim et al. [5], Kiriacou et al. [28,29], and Wojdylo et al. [30] have observed, the nutrient content of lettuce is determined by genetics, environmental influence, genotype-environment interactions, and plants' harvest stage. Microgreens and baby lettuces may have significantly higher levels of vitamins, minerals, and other health beneficial phytonutrients than mature leaves. For these reasons, these types of seedlings are now appreciated as functional foods [31-35]. Seeds are a source of proteins, carbohydrates, and sometimes fats but not vitamins [36]. However, germination and embryo growth promote intense metabolic activity in seeds, in which several chemical reactions take place, including enzyme synthesis. Most carbohydrates and fats are reused in the synthesis of vitamins, sugars, proteins, and mineral salts [36]. Because of these processes, seedlings are considered as functional foods with substantial health-promoting properties [33]. This statement is reflected in our study because the studied varieties' antioxidant capacity, including the main antioxidant compounds, such as ascorbic acid and 
phenols, showed a clear pattern that was repeated in all cultivars that microgreens and baby greens presented higher antioxidant properties than adult plants.

Phenols and ascorbic acid serve as scavengers of reactive oxygen species to protect young expanding leaves that are prone to light damage [17]. Phenolic compounds also seem to influence the sensory qualities of microgreens. In this regard, Xiao et al. [37] reported that the total Phe concentration correlates with the overall eating quality and several sensory qualities. According to Manjula et al., leafy vegetable microgreens present 2- to 5-fold more nutrients than mature leaves from adult vegetables [38]. In our study, this tendency was proven because the Phe content was almost 5-fold higher in seedlings than in adult lettuces regardless of the variability observed among varieties. Our results about adult lettuces are in line with Liu et al. [39], Mmapholo et al. [26], Huang et al. [40], and Kim et al. [5], who claimed that red-leaf adult cultivars have greater total Phe contents. This finding was observed in our trial as highlighted by the varieties CL4 and L11. These results are higher than the values reported by several authors for red lettuce cultivars $[5,26,27,41]$ and are also higher than the values obtained from vegetables and fruit with known for elevated Phe contents, such as spinach (2.69 $\left.\mathrm{mg} \mathrm{g}^{-1} \mathrm{FW}\right)$ [42], red onion (2.53-3.11 $\mathrm{mg} \mathrm{g}^{-1} \mathrm{FW}$ ) [43], strawberry (3.64 $\left.\mathrm{mg} \mathrm{g}^{-1} \mathrm{FW}\right)$ [43], plum (3.04 $\left.\mathrm{mg} \mathrm{g}^{-1} \mathrm{FW}\right)$, and blueberry ( $4.25 \mathrm{mg} \mathrm{g}^{-1} \mathrm{FW}$ ) [44]. In the initial development stages, the Phe content of the varieties CL4 and L11 is similar to that of other varieties a priori qualified as less reddish, such as L3 and L5 in the baby green stage. However, compared to the Phe content in many other cultivar microgreens, such as beetroot $\left(166 \mathrm{mg} \mathrm{g}^{-1} \mathrm{FW}\right)$ or amaranth (586 $\mathrm{mg} \mathrm{g}^{-1} \mathrm{FW}$ ) [30], lettuce microgreen cultivation is not remarkable. This fact does not seem to affect consumer choice because lettuce and carrot are some of the most preferred microgreens, followed by green peas, red amaranth, and finger millet [45].

Likewise, significant differences were detected when determining the total vitamin $C$ concentration of the varieties. In addition, the AsA content was $41 \%$ higher in the seedling stages than in adult lettuces. Similar to phenols, the red varieties CL4 and L11 stood out from the rest. Similarly, when comparing our results to those of other authors [27,46,47], the obtained values, especially those in landraces, regarding the vitamin C content were higher for our varieties to to equivalent ones in terms of the lettuce type, based mainly on the color or head structure, in other articles. These results are similar to the vitamin $C$ values obtained for other species: peas (30.9 mg $\left.100 \mathrm{~g}^{-1} \mathrm{FW}\right)$, spinach (31.6 mg $\left.100 \mathrm{~g}^{-1} \mathrm{FW}\right)$, green beans (15.1 mg $100 \mathrm{~g} \mathrm{~g}^{-1} \mathrm{FW}$ ) [48], grapefruit (39.0 mg $\left.100 \mathrm{~g}^{-1} \mathrm{FW}\right)$, banana (11.1 $\mathrm{mg} 100 \mathrm{~g}^{-1} \mathrm{FW}$ ), and mango (37.0 mg $100 \mathrm{~g}^{-1} \mathrm{FW}$ ) [49]. Even colored lettuce varieties show vitamin values similar to crops known for their high ascorbic contents, for example, orange (49.4 mg $100 \mathrm{~g}^{-1} \mathrm{FW}$ ), pepper (50.3 mg $100 \mathrm{~g}^{-1} \mathrm{FW}$ ) [50], mandarin (57.4 mg $\left.100 \mathrm{~g}^{-1} \mathrm{FW}\right)$, and

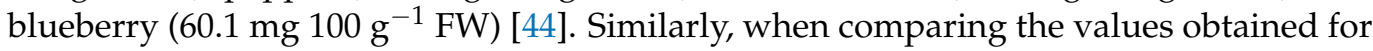
the microgreens and baby greens, even the values obtained in microgreens and baby greens equaled those obtained for broccoli $\left(77.1 \mathrm{mg} 100 \mathrm{~g}^{-1} \mathrm{FW}\right)$ [48] and strawberry (77.3 mg $100 \mathrm{~g}^{-1} \mathrm{FW}$ ) [49]. These values are also comparable to those detected in other microgreen species, such as carrot $\left(65.6 \mathrm{mg} 100 \mathrm{~g}^{-1} \mathrm{FW}\right)$, onion (29.9 $\left.\mathrm{mg} 100 \mathrm{~g}^{-1} \mathrm{FW}\right)$, spinach (71.2 $\mathrm{mg}$

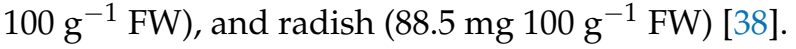

The antioxidant capacity followed the same pattern as the phenolic compounds and vitamin $C$ contents, and was more prominent in the microgreen and baby green stages. However, as no quantification was carried out, we were unable to perform a comparison with other crops, and only a comparison of the varieties under study was feasible. As previously mentioned, landrace L11 stood out in the adult stage. These data imply that both phenols and vitamin $C$ are determinants of the generally increased antioxidant capacity of this crop because the varieties that stood out for these nutraceutical compounds tended to have a much higher antioxidant capacity.

Similarly, some of the analyzed pigments are also apparently involved in the total antioxidant capacity, especially anthocyanins, the content of which is high in red-colored lettuce [51-53]. Moreover, several authors, such as Llorach et al. [41], Baslam et al. [54], and Kim et al. [5], have claimed that red pigmentation is indicative of the total Ant and 
Phe content, which also corroborates the correlations found between these two parameters together with the total antioxidant capacity in baby and adult lettuces. Nevertheless, no correlations were found in microgreens, perhaps because at the time of the seedlings' initial growth, metabolic activity intensifies after germination [36], and anthocyanins begin to be synthesized together with the other phenolic compounds, but their antioxidant properties are still irrelevant. In addition, a strong genetic component or environmental factors, such as light, may also affect the synthesis and activity of anthocyanins because the anthocyanins concentration does not seem to follow a clear pattern but varies between varieties in different ways.

The nutritional value of lettuce varies for different varieties and environmental conditions $[5,29,36,55]$. Among the environmental factors, light is one of the most important variables that affects phytochemical concentrations in plants. Light conditions influence the morpho-physiology of microgreens, together with the biosynthesis and accumulation of phytochemicals [56-58]. According to Mou and Ryder [10], the lower nutritional value of some varieties is due to the marked enclosure of their leaves in the head structure as most of the edible head structure portion includes leaves that are not exposed to light. Moreover, the size and number of external leaves and the head type lead to differences in the light microenvironment between outer and inner leaves [54]. One clear example is the lower nutrient content of crisphead lettuce versus romaine types [59]. Of the varieties included in our study, only CL5, a commercial iceberg variety, was confirmed to have the lowest values of vitamin C, DPPH, Chl, DW, and Phe. It was undoubtedly the variety with the highest degree of leaf overlap in our study. However, the variety CL4, a variety with the most patent buds, stood out for its high proportion of nutraceutical compounds. This could be due to its characteristic purple color, which is indicative of high Ant and Car contents. Conversely, the Roman purple variety L11, which was the variety with the lowest degree of leaf overlap, stood out for almost every analyzed phytochemical. Indeed, the different degrees of leaf overlap between our varieties could have influenced the variability of the studied compounds in the adult stage. Likewise, as our analyses were carried out in different lettuce development stages, the nutritional quality pattern between varieties was not maintained as no head structure was present in the youngest stages (microgreens and baby). This meant that varieties were highlighted when microgreens were not necessarily the most outstanding in the baby leaf or adult stages. In this regard, as consumers, food nutritionists, and producers are showing more interest in the health-related effects of the products they eat [6], the information presented herein could be helpful to guide consumers in their diet choices.

As mentioned earlier, the anthocyanin synthesis rate appeared to be variety dependent as no firm pattern was observed for production throughout the development of the studied varieties. For microgreens, narrow variability was observed between varieties and the Ant content did not seem to be proportional to the color of these seedlings, which occurred in more advanced development stages. This implies that other pigments absorbed at the same wavelength as anthocyanins were synthesized on a large scale. This could interfere with color determination in microgreens. Some perfect examples of this statement are the varieties CL4 (with a completely red first true leaf) and L1 (completely green-colored seedlings). Landrace L1 had the highest Ant concentration in our study (65 $\left.\mu \mathrm{mol} 100 \mathrm{~g}^{-1} \mathrm{FW}\right)$ while CL4 matched the varieties with the lowest concentration $\left(36.8 \mu \mathrm{mol} 100 \mathrm{~g}^{-1} \mathrm{FW}\right)$ in the microgreen stage. In the following development stages, the reddish plant coloration was in accordance with the measured anthocyanin concentration. The variety CL4 in the baby green stage $\left(155 \mu \mathrm{mol} 100 \mathrm{~g}^{-1} \mathrm{FW}\right)$ and landrace L11 in the adult stage $\left(70.65 \mu \mathrm{mol} 100 \mathrm{~g}^{-1} \mathrm{FW}\right)$ were highlighted and, thus confirm the theory that red lettuce coloration is indicative of Ant content $[5,41,54,60]$.

This also supports the notion that the higher the Ant content, the greater the light exposure [60], which was favored by low degrees of leaf overlap (open lettuce vs. crisphead formats), in addition to longer exposure times (adult vs. early stages). 
As previously reported, differences in the carotenoids content between lettuce types has been suggested to be related to the head structure because it is regulated by light $[5,10]$. In addition, the increase in these pigments is beneficial due to their antioxidant properties $[26,61]$. In the juvenile development stages, the positive correlation between carotenoids and phenols was irrelevant, but the trend was positive and became statistically significant when plants reached maturity. This indicates the contribution of these pigments to the total antioxidant activity. This event has also been observed in ginger [62] and palm oils [63]. In our study, the lack of a direct correlation between carotenes and the antioxidant capacity of lettuce in all the development stages could be due to the antioxidant role of carotenes not being as relevant as that of phenols, anthocyanins, or vitamin C. Regardless of the observed wide inter-varietal variability, the carotenoids content in microgreens was practically null while the highest values were observed for baby plants. According to Wojdylo et al. [30], these results are unexpected because he claims that microgreens contain high levels of carotenoids and chlorophylls, among others. This could indicate that the machinery used for carotenoid production is activated late during development. Once again, the need to know each variety and its optimum harvesting period to obtain the best nutritional benefit is highlighted. The highest Car values were observed for the varieties L11 (114.2 $\left.\mathrm{g} \mathrm{g} \mathrm{g}^{-1} \mathrm{FW}\right)$, CL4 $\left(51.5 \mu \mathrm{g} \mathrm{g}^{-1} \mathrm{FW}\right)$, and L10 $\left(48.9 \mu \mathrm{g} \mathrm{g}^{-1} \mathrm{FW}\right)$ in the baby stage. In particular, the value obtained for landrace L11 was comparable to other crops known for their high carotenoid contents, such as red peppers $\left(63-130 \mu \mathrm{g} \mathrm{g}^{-1} \mathrm{FW}\right)[64,65]$ and carrots $\left(95.9 \mu \mathrm{g} \mathrm{g}^{-1} \mathrm{FW}\right)[66]$.

As far as the Chl content is concerned, it has been shown to depend not only on light itself, but also on the quality of this resource [67]. Similarly, it has been demonstrated that Fe is responsible for the biosynthesis of this pigment, at least the water-soluble Fe fraction [68]. Fe-deficient plants are usually characterized by the development of marked chlorosis, which lowers both the chlorophyll and carotenoid concentrations [69]. However, in our study, we observed a negative relation between the $\mathrm{Chl}$ content and the total Fe concentration, which became more pronounced in the adult plant stage. When focusing on this development stage, the relation between Ant and Chl was also negative while that with Fe was positive. As this study did not use an Fe-deficient environment, and as all the varieties ranged within the optimal Fe concentration for this crop in the adult stage (0.41-2 mg $100 \mathrm{~g}^{-1} \mathrm{FW}$ [59]), this might indicate that reddish varieties have a greater capacity to absorb or accumulate Fe, likely thorough more efficient Fe acquisition or transport systems. This does not imply that greener ones are Fe deficient and are therefore not capable of producing Chls. One clear example of this statement would be CL2. This variety has completely green leaves and is one of the accessions with the highest $\mathrm{Chl}$ content in our study but was ranked last regarding the Fe concentration. Other factors could also affect this relation, such as the contents of other pigments, such as carotenes, or other minerals also related to chlorophyll synthesis, such as Mg, which is a structural constituent of chlorophylls [70].

For $\mathrm{Ca}$, a similar trend to that observed for Fe was noted because significant relations between this mineral and other phytonutrients were detected in the adult stage. The Ca concentration was generally higher in microgreens. This finding coincides with Pinto et al. [9]. In our assay, once plants reached maturity, the concentration of this mineral appeared to be correlated with the content of the main antioxidant compounds. The benefits derived from Ca application are well known, especially in postharvest activities, maintaining cell turgor and tissue firmness, delaying the catabolism of membrane lipids [71], and reducing fruit browning [72] by prolonging the storage life of fresh fruit [73]. Similarly, there is evidence that Ca promotes anthocyanin synthesis in vitro [74]. Although these facts may support the relation between $\mathrm{Ca}$ and the major antioxidants in lettuce, $\mathrm{Ca}$ can be obtained from the substrate, and plays an essential role in plant development and overall plant health. In lettuce leaf tissue, an increase in $\mathrm{Ca}$ enhances both the photosynthetic capacity and chlorophyll synthesis $[75,76]$, which implies greater primary production of glucose and fructose from photosynthesis [76]. 
Finally, $\mathrm{K}$ is one of three major nutrients required for normal plant growth, and is involved in plant photosynthesis, transpiration, growth, and development [75]. Several studies have suggested that plant growth and yield are strongly affected by substrate $\mathrm{K}$ availability $[77,78]$. Our study did not carry out a comparative study between different substrate types. This only confirms that some varietal genetic differences enable them to capture and/or retain a certain $\mathrm{K}$ concentration What we were able to verify was the tendency to accumulate this mineral in lettuce leaves throughout development, which was explained by Kyriacou et al. [34], Pinto et al. [9], and el El-Nakhel et al. [17]. The K concentration in mature leaves was much higher than in microgreens for almost all varieties under study.

\section{Conclusions}

Considering lettuce's fraction of functional compounds and its high consumption rate, it constitutes a very interesting source of nutrients (minerals and functional compounds). The results of the present study show that the nutrient content depends on the lettuce type, color, and development stage. Comparative nutrient data of several popularly consumed lettuce cultivars were obtained and analyzed, which will help consumers to choose foods with higher nutritional value.

Of all the studied varieties, landrace L11 was significant in all the studied stages and in almost all the analyzed parameters. This indicates the significantly high potential of this traditional reddish variety, and is of interest to consumers because of its attractive color. However, except for the commercial variety CL4, for the other studied cases, it is advisable to promote the production of varieties in stages other than the adult stage. Some examples of this include: CL5, which was found to be the most deficient in phytonutrients upon maturity but had high DPPH and AsA contents in microgreens; landrace L5, a variety that was not particularly significant in the analysis, and was observed to have significant total DPPH and Chl, Car, and AsA contents in the baby green stage. In turn, this underscores the idea of the significant existing but barely exploited variability of traditional varieties.

Supplementary Materials: The following are available online at https:/ /www.mdpi.com/article/10 .3390/foods11030423/s1, Table S1: The sodium (Na), magnesium (Mg), phosphorus (P), sulphur (S), Zinc $(\mathrm{Zn})$, manganese $(\mathrm{Mn})$ and silicon $(\mathrm{Si})$ concentrations in the collection of the 11 lettuce varieties evaluated in the three development stages (microgreen, baby, adult). Values are the mean \pm SE of four replicates per variety. The means are subjected to a one-way ANOVA analysis. Different capital and lowercase letters indicate significant differences between varieties and development stages, respectively, at $p<0.05$ using the LSD test. DW: Dry weight.

Author Contributions: Conceptualization, Á.C., M.-R.M.-C. and E.M.-I.; Methodology, Á.C., E.M.-I., M.-R.M.-C., J.I.M., C.C., F.B. and A.A.; Validation, Á.C., E.M.-I. and M.-R.M.-C.; Formal Analysis, E.M.-I. and M.-R.M.-C.; Investigation, Á.C., M.-R.M.-C. and E.M.-I.; Resources, Á.C., S.S. and J.V.V.; Data curation, Á.C. and M.-R.M.-C.; Writing-Original Draft Preparation, E.M.-I. and M.-R.M.-C.; Writing-Review \& Editing, Á.C., S.S. and M.-R.M.-C.; Supervision, Á.C., S.S. and J.V.V.; Funding Acquisition, Á.C., S.S. and J.V.V. All authors have read and agreed to the published version of the manuscript.

Funding: This work is included in Project 51903, cofunded by the European Union through the European Regional Development Fund (ERDF) of the Generalitat Valenciana 2014-2020.

Institutional Review Board Statement: Not applicable.

Informed Consent Statement: Not applicable.

Data Availability Statement: The datasets generated for this study are available on request to the corresponding author.

Acknowledgments: This work was funded by the Generalitat Valenciana and FEDER funds.

Conflicts of Interest: The authors declare that the research was conducted without any commercial or financial relationships that could be construed as a potential conflict of interest. 


\section{References}

1. Kenny, O.; O'Beirne, D. The effects of washing treatment on antioxidant retention in ready-to-use iceberg lettuce. Int. J. Food Sci. Technol. 2009, 44, 1146-1156. [CrossRef]

2. Kris-Etherton, P.M.; Hecker, K.D.; Bonanome, A.; Coval, S.M.; Binkoski, A.E.; Hilpert, K.F.; Griel, A.E.; Etherton, T.D. Bioactive compounds in foods: Their role in the prevention of cardiovascular disease and cancer. Am. J. Med. 2002, 113, 71-88. [CrossRef]

3. Soetan, K.O.; Olaiya, C.O.; Oyewole, O.E. The importance of mineral elements for humans, domestic animals and plants-A review. Afr. J. Food Sci. 2010, 4, 200-222. [CrossRef]

4. Rouphael, Y.; Kyriacou, M.C.; Petropoulos, S.A.; De Pascale, S.; Colla, G. Improving vegetable quality in controlled environments. Sci. Hortic. 2018, 234, 275-289. [CrossRef]

5. Kim, M.J.; Moon, Y.; Kopsell, D.A.; Park, S.; Tou, J.C.; Waterland, N.L. Nutritional value of Crisphead 'Iceberg' and Romaine lettuces (Lactuca sativa L.). J. Agric. Sci. 2016, 8, 1. [CrossRef]

6. Colonna, E.; Rouphael, Y.; Barbieri, G.; De Pascale, S. Nutritional quality of ten leafy vegetables harvested at two light intensities. Food Chem. 2016, 199, 702-710. [CrossRef]

7. Łata, B.; Przeradzka, M. Glutathione and ascorbate contents in broccoli and lettuce cultivars. Folia Hort. 1999, 11, 13-22.

8. Gazula, A.; Kleinhenz, M.D.; Scheerens, J.C.; Ling, P.P.; Streeter, J.G. Temperature and genotype affect anthocyanin concentrations in lettuce (Lactuca sativa). HortScience 2004, 39, 864A. [CrossRef]

9. Pinto, E.; Almeida, A.A.; Aguiar, A.A.; Ferreira, I.M. Comparison between the mineral profile and nitrate content of microgreens and mature lettuces. J. Food Compos. Anal. 2015, 37, 38-43. [CrossRef]

10. Mou, B.; Ryder, E.J. Relationship between the nutritional value and the head structure of lettuce. Acta Hortic. 2004, 637, 361-367. [CrossRef]

11. Figàs Moreno, M.; Raigón Jiménez, M.; Casanova Calancha, C.; Soler, E.; Pereira Dias, L.; García Martínez, M.; Rosa, E.; Martín, A.; Prohens Tomás, J.; Soler Aleixandre, S. Caracterización de una colección de variedades tradicionales valencianas de lechuga ("Lactuca sativa" L.). Agric. Vergel Frutic. Hortic. Floric. 2017, 401, 157-164.

12. Kosma, C.; Triantafyllidis, V.; Papasavvas, A.; Salahas, G.; Patakas, A. Yield and nutritional quality of greenhouse lettuce as affected by shading and cultivation season. Emir. J. Food Agric. 2013, 25, 974-979. [CrossRef]

13. Mir, S.A.; Shah, M.A.; Mir, M.M. microgreens: Production, shelf life, and bioactive components. Crit. Rev. Food Sci. Nutr. 2017, 57, 2730-2736. [CrossRef]

14. Treadwell, D.; Hochmuth, R.; Landrum, L.; Laughlin, W. Microgreens: A New Specialty Crop; University of Florida IFAS Extension HS1164: Gainesville, FL, USA, 2010.

15. Xiao, Z.; Lester, G.E.; Luo, Y.; Wang, Q. Assessment of vitamin and carotenoid concentrations of emerging food products: Edible microgreens. J. Agric. Food Chem. 2012, 60, 7644-7651. [CrossRef] [PubMed]

16. Weber, C.F. Nutrient content of cabbage and lettuce microgreens grown on vermicompost and hydroponic growing pads. J. Hortic. 2016, 3, 1-6. [CrossRef]

17. El-Nakhel, C.; Pannico, A.; Graziani, G.; Kyriacou, M.C.; Giordano, M.; Ritieni, A.; De Pascale, S.; Rouphael, Y. Variation in macronutrient content, phytochemical constitution and in vitro antioxidant capacity of green and red Butterhead lettuce dictated by different developmental stages of harvest maturity. Antioxidants 2020, 9, 300. [CrossRef]

18. Ebert, A.W. Potential of underutilized traditional vegetables and legume crops to contribute to food and nutritional security, income and more sustainable production systems. Sustainability 2014, 6, 319. [CrossRef]

19. Penella, C.; Nebauer, S.G.; Bautista, A.S.; López-Galarza, S.; Calatayud, Á. Rootstock alleviates PEG-induced water stress in grafted pepper seedlings: Physiological responses. J. Plant Physiol. 2014, 171, 842-851. [CrossRef]

20. Maroto, J.V. Horticultura Herbácea Especial, 5th ed.; Mundi-Prensa: Madrid, Spain, 2002.

21. Porra, R.J.; Thompson, W.A.; Kriedemann, P.E. Determination of accurate extinction coefficients and simultaneous equations for assaying chlorophylls a and b extracted with four different solvents: Verification of the concentration of chlorophyll standards by atomic absorption spectroscopy. BBA-Bioenerg. 1989, 975, 384-394. [CrossRef]

22. Szepesi, Á.; Csiszár, J.; Gallé, Á.; Gémes, K.; Poór, P.; Tari, I. Effects of long-term salicylic acid pre-treatment on tomato (Lycopersicon esculentum Mill. L.) salt stress tolerance: Changes in glutathione S-transferase activities and anthocyanin contents. Acta Agron. Hung. 2008, 56, 129-138. [CrossRef]

23. Kampfenkel, K.; Van Montagu, M.; Inzé, D. Extraction and determination of ascorbate and dehydroascorbate from plant tissue. Anal. Biochem. 1995, 225, 165-167. [CrossRef] [PubMed]

24. Dewanto, V.; Xianzhong, W.; Adom, K.K.; Liu, R.H. Thermal processing enhances the nutritional value of tomatoes by increasing total antioxidant activity. J. Agric. Food Chem. 2002, 50, 3010-3014. [CrossRef] [PubMed]

25. Brand-Williams, W.; Cuvelier, M.E.; Berset, C. Use of a free radical method to evaluate antioxidant activity. LWT-Food Sci. Technol. 1995, 28, 25-30. [CrossRef]

26. Mampholo, B.M.; Maboko, M.M.; Soundy, P.; Sivakumar, D. Phytochemicals and overall quality of leafy lettuce (Lactuca sativa L.) varieties grown in closed hydroponic system. J. Food Qual. 2016, 39, 805-815. [CrossRef]

27. Mou, B. Nutritional quality of lettuce. Curr. Nutr. Food Sci. 2012, 8, 177-187. [CrossRef]

28. Kyriacou, M.C.; Rouphael, Y.; Di Gioia, F.; Kyratzis, A.; Serio, F.; Renna, M.; De Pascale, S.; Santamaria, P. Micro-scale vegetable production and the rise of microgreens. Trends Food Sci. Technol. 2016, 57, 103-115. [CrossRef] 
29. Kyriacou, M.C.; El-Nakhel, C.; Pannico, A.; Graziani, G.; Soteriou, G.A.; Giordano, M.; Palladino, M.; Ritieni, A.; De Pascale, S.; Rouphael, Y. Phenolic constitution, phytochemical and macronutrient content in three species of microgreens as modulated by natural fiber and synthetic substrates. Antioxidants 2020, 9, 252. [CrossRef]

30. Wojdyło, A.; Nowicka, P.; Tkacz, K.; Turkiewicz, I.P. Sprouts vs. Microgreens as novel functional foods: Variation of nutritional and phytochemical profiles and their in vitro bioactive properties. Molecules 2020, 25, 4648. [CrossRef]

31. Choe, U.; Yu, L.L.; Wang, T.T. The science behind microgreens as an exciting new food for the 21st century. J. Agric. Food Chem. 2018, 66, 11519-11530. [CrossRef]

32. Lenzi, A.; Orlandini, A.; Bulgari, R.; Ferrante, A.; Bruschi, P. Antioxidant and mineral composition of three wild leafy species: A comparison between microgreens and baby greens. Foods 2019, 8, 487. [CrossRef]

33. Le, T.N.; Chiu, C.; Hsieh, P. Microgreens: An updated overview from a nutraceutical perspective. Plants 2020, 9, 946. [CrossRef] [PubMed]

34. Kyriacou, M.C.; El-Nakhel, C.; Graziani, G.; Pannico, A.; Soteriou, G.A.; Giordano, M.; Ritieni, A.; De Pascale, S.; Rouphael, Y. Functional quality in novel food sources: Genotypic variation in the nutritive and phytochemical composition of thirteen microgreens species. Food Chem. 2019, 277, 107-118. [CrossRef] [PubMed]

35. Choe, U.; Li, Y.; Gao, B.; Yu, L.; Wang, T.T.Y.; Sun, J.; Chen, P.; Liu, J.; Yu, L. Chemical compositions of cold-pressed broccoli, carrot, and cucumber seed flours and their in vitro gut microbiota modulatory, anti-inflammatory, and free radical scavenging properties. J. Agric. Food Chem. 2018, 66, 9309-9317. [CrossRef] [PubMed]

36. Castagnino, A.; Marina, J.; Benvenuti, s.; Castro, M. Microgreens and sprouts, two innovative functional foods for a healthy diet in Km 0. Hortic. Argent. 2020, 39, 55-95.

37. Xiao, Z.; Lester, G.E.; Park, E.; Saftner, R.A.; Luo, Y.; Wang, Q. Evaluation and correlation of sensory attributes and chemical compositions of emerging fresh produce: Microgreens. Postharvest Biol. Technol. 2015, 110, 140-148. [CrossRef]

38. Ghoora, M.D.; Babu, D.R.; Srividya, N. Nutrient composition, oxalate content and nutritional ranking of ten culinary microgreens. J. Food Compos. Anal. 2020, 91, 103495. [CrossRef]

39. Liu, X.; Ardo, S.; Bunning, M.; Parry, J.; Zhou, K.; Stushnoff, C.; Stoniker, F.; Yu, L.; Kendall, P. Total phenolic content and DPPH radical scavenging activity of lettuce (Lactuca sativa L.) grown in Colorado. LWT-Food Sci. Technol. 2007, 40, 552-557. [CrossRef]

40. Huang, H.; Jiang, X.; Xiao, Z.; Yu, L.; Pham, Q.; Sun, J.; Chen, P.; Yokoyama, W.; Yu, L.L.; Luo, Y.S.; et al. Red cabbage microgreens lower circulating low-density lipoprotein (LDL), liver cholesterol, and inflammatory cytokines in mice fed a high-fat diet. J. Agric. Food Chem. 2016, 64, 9161-9171. [CrossRef]

41. Llorach, R.; Martínez-Sánchez, A.; Tomás-Barberán, F.A.; Gil, M.I.; Ferreres, F. Characterisation of polyphenols and antioxidant properties of five lettuce varieties and escarole. Food Chem. 2008, 108, 1028-1038. [CrossRef]

42. Ribarova, F.; Atanassova, M.; Marinova, D.; Ribarova, F.; Atanassova, M.J. Total phenolics and flavonoids in Bulgarian fruits and vegetables. Chem. Technol. 2005, 40, 255-260.

43. Lin, J.Y.; Tang, C.Y. Determination of total phenolic and flavonoid contents in selected fruits and vegetables, as well as their stimulatory effects on mouse splenocyte proliferation. Food Chem. 2007, 101, 140-147. [CrossRef]

44. Jabłonska-Rys, E.; Zalewska-Korona, M.; Kalbarczyk, J. Antioxidant capacity, ascorbic acid and phenolics content in wild edible fruits. J. Fruit Ornam. Plant Res. 2009, 17, 115-120.

45. Senevirathne, G.I.; Gama-Arachchige, N.S.; Karunaratne, A.M. Germination, harvesting stage, antioxidant activity and consumer acceptance of ten microgreens. Ceylon J. Sci. 2019, 48, 91. [CrossRef]

46. Viacava, G.E.; Gonzalez-Aguilar, G.; Roura, S.I. Determination of phytochemicals and antioxidant activity in butterhead lettuce related to leaf age and position. J. Food Biochem. 2014, 38, 352-362. [CrossRef]

47. Medina-Lozano, I.; Bertolín, J.R.; Díaz, A. Nutritional value of commercial and traditional lettuce (Lactuca sativa L.) and wild relatives: Vitamin C and anthocyanin content. Food Chem. 2021, 359. [CrossRef]

48. Favell, D.J. A comparison of the vitamin C content of fresh and frozen vegetables. Food Chem. 1998, 62, 59-64. [CrossRef]

49. Szeto, Y.T.; Tomlinson, B.; Benzie, I.F.F. Total antioxidant and ascorbic acid content of fresh fruits and vegetables: Implications for dietary planning and food preservation. Br. J. Nutr. 2002, 87, 55-59. [CrossRef]

50. Kapur, A.A.; Hasković, A.; Čopra-Janićijević; Klepo, L. Spectrophotometric analysis of total ascorbic acid contetnt in various fruits and vegetables. Glas. Hem. Tehnol. Bosne Herceg. 2012, 38, 39-42.

51. Igarashi, K.; Kimura, Y.; Takenaka, A. Preventive Effects of dietary cabbage acylated anthocyanins on paraquat-induced oxidative stress in rats. Biosci. Biotechnol. Biochem. 2000, 64, 1600-1607. [CrossRef]

52. Simko, I.; Hayes, R.J.; Furbank, R.T. Non-destructive phenotyping of lettuce plants in early stages of development with optical sensors. Front. Plant Sci. 2016, 7, 1985. [CrossRef]

53. Sytar, O.; Zivcak, M.; Bruckova, K.; Brestic, M.; Hemmerich, I.; Rauh, C.; Simko, I. Shift in accumulation of flavonoids and phenolic acids in lettuce attributable to changes in ultraviolet radiation and temperature. Sci. Hortic. 2018, 239, 193-204. [CrossRef]

54. Baslam, M.; Morales, F.; Garmendia, I.; Goicoechea, N. Nutritional quality of outer and inner leaves of green and red pigmented lettuces (Lactuca sativa L.) consumed as salads. Sci. Hortic. 2013, 151, 103-111. [CrossRef]

55. Brücková, K.; Sytar, O.; Ẑivçák, M.; Brestič, M.; Lebeda, A. Vplyv podmienok pestovania na akumuláciu flavonolov a antokyánov v zelenom a červenom šaláte. J. Cent. Eur. Agric. 2016, 17, 986-997. [CrossRef]

56. Delian, E.; Chira, A.; Bădulescu, L.; Chira, L. Insights into microgreens physiology. Sci. Pap. Ser. B Hortic. 2015, 59, 447-454. 
57. Pérez-Balibrea, S.; Moreno, D.A.; García-Viguera, C. Influence of light on health-promoting phytochemicals of broccoli sprouts. J. Sci. Food Agric. 2008, 88, 904-910. [CrossRef]

58. Meas, S.; Luengwilai, K.; Thongket, T. Enhancing growth and phytochemicals of two amaranth microgreens by LEDs light irradiation. Sci. Hortic. 2020, 265, 109204. [CrossRef]

59. Mou, B. Nutrient content of lettuce and its improvement. Curr. Nutr. Food Sci. 2009, 5, 242-248. [CrossRef]

60. Sytar, O.; Brücková, K.; Kovár, M.; Živčák, M.; Hemmerich, I.; Brestič, M. Nondestructive detection and biochemical quantification of buckwheat leaves using visible (VIS) and near-infrared (NIR) hyperspectral reflectance imaging Nedeštrukčná detekcia a biochemická kvantifikácia listov pohánky s využitím hyperspektrálneho zobrazovania s reflektanciou vo viditel'nej (VIS) a blízkej infračervenej (NIR) oblasti. J. Cent. Eur. Agric. 2017, 18, 864-878. [CrossRef]

61. Stahl, W.; Sies, H. Bioactivity and protective effects of natural carotenoids. Proc. Bioch. Biop. Acta. 2005, 1740, 101-107. [CrossRef]

62. Yan, W.; Frégeau-Reid, J. Breeding line selection based on multiple traits. Crop Sci. 2008, 48, 417-423. [CrossRef]

63. Szydłowska-Czerniak, A.; Trokowski, K.; Karlovits, G.; Szłyk, E. Effect of refining processes on antioxidant capacity, total contents of phenolics and carotenoids in palm oils. Food Chem. 2011, 129, 1187-1192. [CrossRef]

64. Gisbert-Mullor, R.; Ceccanti, C.; Padilla, Y.G.; López-Galarza, S.; Calatayud, Á.; Conte, G.; Guidi, L. Effect of grafting on the production, physico-chemical characteristics and nutritional quality of fruit from pepper landraces. Antioxidants 2020, 9, 501. [CrossRef] [PubMed]

65. Martínez-Ispizua, E.; Martínez-Cuenca, M.-R.; Marsal, J.I.; Díez, M.J.; Soler, S.; Valcárcel, J.V.; Calatayud, Á. Bioactive compounds and antioxidant capacity of valencian pepper landraces. Molecules 2021, 26, 1031. [CrossRef] [PubMed]

66. Qudah, J.; El-Qudah, J.M. Identification and quantification of major carotenoids in some vegetables evaluation of hospital diets view project identification and quantification of major carotenoids in some vegetables. Am. J. Appl. Sci. 2009, 6, $492-497$. [CrossRef]

67. Wang, J.; Lu, W.; Tong, Y.; Yang, Q. Leaf morphology, photosynthetic performance, chlorophyll fluorescence, stomatal development of lettuce (Lactuca sativa L.) exposed to different ratios of red light to blue light. Front. Plant Sci. 2016, 7, 250. [CrossRef] [PubMed]

68. Briat, J.-F.; Vert, G. Acquisition et gestion du fer par les plantes. Cah. Agric. 2004, 13, 183-201.

69. Msilini, N.; Amdouni, T.; Chebbi, M.; Lachaâl, M.; Ouerghi, Z. Antagonistic effects of iron and/or magnesium deficiencies on enzyme activities in lettuce (Lactuca sativa L.) plants. J. Hortic. Sci. Biotechnol. 2014, 89, 361-366. [CrossRef]

70. Kumar Tewari, R.; Kumar, P.; Nand Sharma, P. Magnesium deficiency induced oxidative stress and antioxidant responses in mulberry plants. Sci. Hortic. 2006, 108, 7-14. [CrossRef]

71. Ciccarese, A.; Stellacci, A.M.; Gentilesco, G.; Rubino, P. Effectiveness of pre- and post-veraison calcium applications to control decay and maintain table grape fruit quality during storage. Postharvest Biol. Technol. 2013, 75, 135-141. [CrossRef]

72. Holb, I.J.; Balla, B.; Vámos, A.; Gáll, J.M. Influence of preharvest calcium applications, fruit injury, and storage atmospheres on postharvest brown rot of apple. Postharvest Biol. Technol. 2012, 67, 29-36. [CrossRef]

73. Rincón, A.; Martínez, E. Funciones del calcio en la calidad poscosecha de frutas y hortalizas. Aliment. Hoy Rev. Asoc. Colomb. y Tecnol. Aliment. 2015, 24, 13-25.

74. Gómez-zeledón, J.; Sc, B.; Jiménez, V.M.; Ph, D. In vitro production of anthocyanins-A literature review. Acta Biol. Colomb. 2011, $16,3-20$.

75. Marschner, H. Mineral Nutrition of Higher Plants, 2nd ed.; Academic Press: Cambridge, MA, USA, 1955.

76. Battistelli, A.; Fallovo, C.; Rouphael, Y.; Cardarelli, M.; Rea, E.; Colla, G.; Rastilantie, M. Yield and quality of leafy lettuce in response to nutrient solution composition and growing season Yield and quality of leafy lettuce in response to nutrient solution composition and growing season WFL Publisher Science and Technology. J. Food, Agric. Environ. 2009, 7, 456-462.

77. Hoque, M.M.; Ajwa, H.; Othman, M.; Smith, R.; Cahn, M. Yield and postharvest quality of lettuce in response to nitrogen, phosphorus, and potassium fertilizers. HortScience 2010, 45, 1539-1544. [CrossRef]

78. Zhang, G.; Johkan, M.; Hohjo, M.; Tsukagoshi, S.; Maruo, T. Plant growth and photosynthesis response to low potassium conditions in three lettuce (Lactuca sativa) types. Hortic. J. 2017, 86, 229-237. [CrossRef] 